\title{
Molecular Epidemiology of Carbapenemases in Enterobacteriales from Humans, Animals, Food and the Environment
}

\author{
Gurleen Taggar ${ }^{1,2}$, Muhammad Attiq Rheman ${ }^{1}$ (D) Patrick Boerlin ${ }^{2}$ and Moussa Sory Diarra ${ }^{1, *}$ \\ 1 Guelph Research and Development Center, Agriculture and Agri-Food Canada (AAFC), 93, Stone Road \\ West, Guelph, ON N1G 5C6, Canada; gtaggar7@gmail.com (G.T.); attiq.muhammad@canada.ca (M.A.R.) \\ 2 Department of Pathobiology, Ontario Veterinary College, University of Guelph, Guelph, ON N1G 2W1, \\ Canada; pboerlin@uoguelph.ca \\ * Correspondence: moussa.diarra@canada.ca
}

Received: 14 September 2020; Accepted: 7 October 2020; Published: 13 October 2020

\begin{abstract}
The Enterobacteriales order consists of seven families including Enterobacteriaceae, Erwiniaceae, Pectobacteriaceae, Yersiniaceae, Hafniaceae, Morganellaceae, and Budviciaceae and 60 genera encompassing over 250 species. The Enterobacteriaceae is currently considered as the most taxonomically diverse among all seven recognized families. The emergence of carbapenem resistance (CR) in Enterobacteriaceae caused by hydrolytic enzymes called carbapenemases has become a major concern worldwide. Carbapenem-resistant Enterobacteriaceae (CRE) isolates have been reported not only in nosocomial and community-acquired pathogens but also in food-producing animals, companion animals, and the environment. The reported carbapenemases in Enterobacteriaceae from different sources belong to the Ambler class A ( $\left.b l a_{\mathrm{KPC}}\right)$, class B $\left(b l a_{\mathrm{IMP}}, b l a_{\mathrm{VIM}}, b l a_{\mathrm{NDM}}\right)$, and class $\mathrm{D}$ (bla $\left.a_{\text {OXA-48 }}\right) \beta$-lactamases. The carbapenem encoding genes are often located on plasmids or associated with various mobile genetic elements (MGEs) like transposons and integrons, which contribute significantly to their spread. These genes are most of the time associated with other antimicrobial resistance genes such as other $\beta$-lactamases, as well as aminoglycosides and fluoroquinolones resistance genes leading to multidrug resistance phenotypes. Control strategies to prevent infections due to CRE and their dissemination in human, animal and food have become necessary. Several factors involved in the emergence of CRE have been described. This review mainly focuses on the molecular epidemiology of carbapenemases in members of Enterobacteriaceae family from humans, animals, food and the environment.
\end{abstract}

Keywords: carbapenemases; Enterobacteriales; human; animal; food; environment

\section{Introduction}

The actual pandemic outbreak of the COVID-19 killing several thousands of people along with its serious negative global economic impacts worldwide is a clear indication that a lot of efforts need to be deployed to fight against infectious diseases and the increased global issue of antimicrobial resistance. The World Health Organization (WHO) published a global priority list of antimicrobial resistant pathogenic bacteria including some Enterobacteriales for which new antibiotics are urgently needed [1]. The genera within the order Enterobacteriales are composed of Gram-negative bacteria of class Gammaproteobacteria, which encompasses many harmless symbiotic and pathogenic strains, including members of the genera Dickeya, Pectobacterium, Brenneria, Erwinia and Pantoea [2]. The pathogenic strains mainly Klebsiella pneumoniae, Yersinia pestis, Escherichia spp., Salmonella enterica serovars and Enterobacter spp. cause a broad range of intestinal and extra intestinal diseases in humans and animals [3]. The expended spectrum cephalosporins (ESC) and cephamycins are frequently used against infectious 
diseases caused by Enterobacteriaceae. Due to the emergence of multidrug resistance, carbapenems in addition to tigecycline and colistin are among the last line of defense against Enterobacteriaceae, because co-resistance to both colistin and tigecycline among the carbapenem-resistant Enterobacteriaceae (CRE) has been rarely reported [4,5]. Carbapenems are a powerful group of broad-spectrum antibiotics which, in many cases, are the last line of defense against multi-resistant bacterial infections. Carbapenems are classified under $\beta$-lactams antibiotics, slightly different from the penicillin by substitution of a carbon atom for a sulfur atom and addition of a double bond to the five-membered ring of the penicillin nucleus (Figure 1).

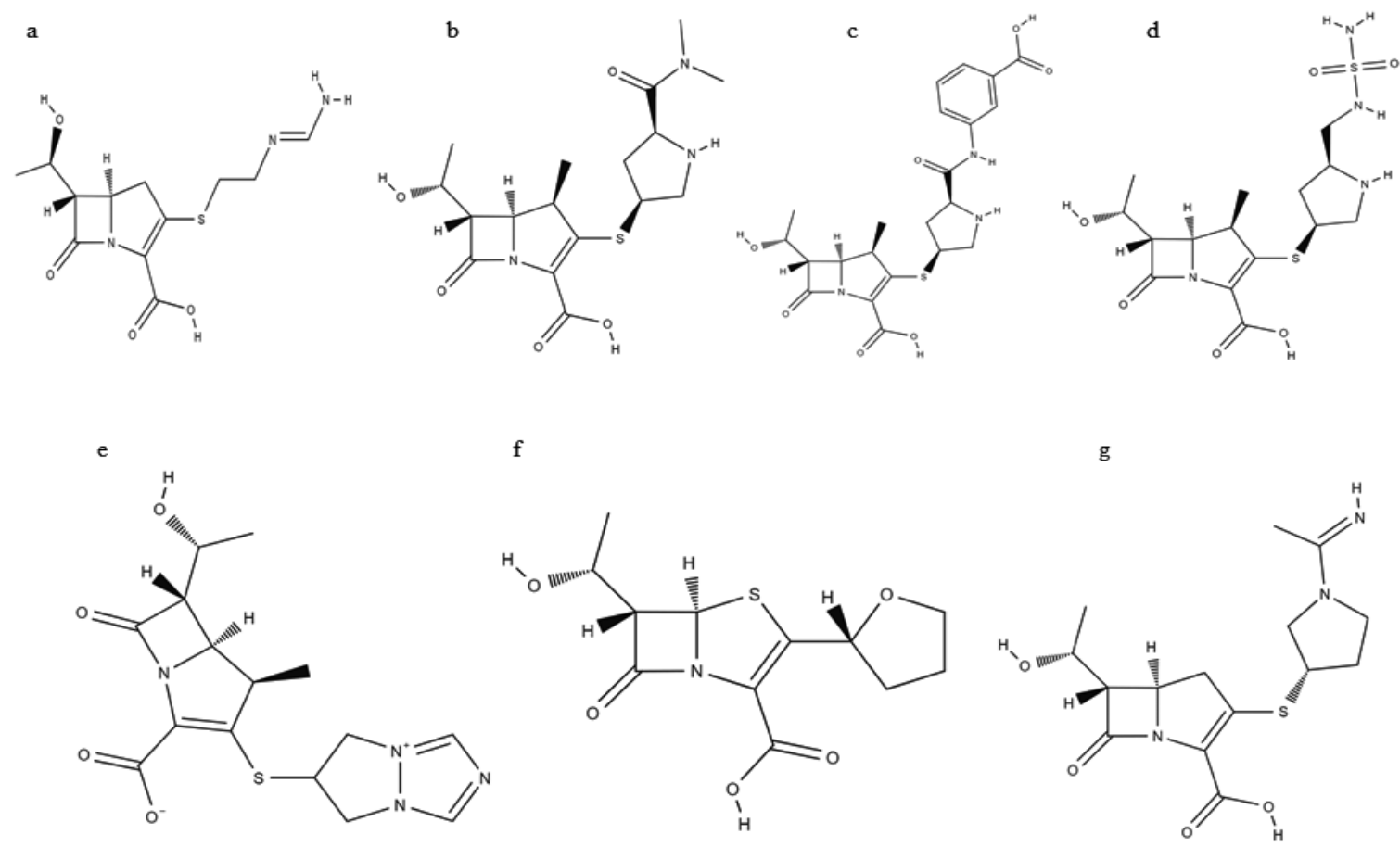

Figure 1. Chemical Structures of various carbapenems: (a) Imipenem; (b) Meropenem; (c) Ertapenem; (d) Doripenem; (e) Biapenem; (f) Faropenem; (g) Panipenem, obtained from the National Center for Biotechnology Information (NCBI) PubChem database.

Carbapenems bind tightly to the bacterial penicillin-binding proteins (PBPs), which are vital for elongation and cross-linkage of the cell wall peptidoglycan, leading to bacterial lysis [6] (Figure 2).

Currently four of carbapenems (imipenem, meropenem, ertapenem and doripenem) are approved for clinical use in the United States of America [7] and additional three of them (biapenem, faropenem, panipenem) in Canada. During the last decade, several monitoring studies have reported the emergence of carbapenem resistant Enterobacteriaceae (CRE) [8]. The three major mechanisms of carbapenem resistance in these bacteria include: (i) the presence of $\beta$-lactamase enzymes called carbapenemases, and (ii) the combined effect of other $\beta$-lactamases with bacterial cell membrane permeability due to alteration or mutations in the porins and/or (iii) increased efflux pump-action (Figure 3). The modification of penicillin binding proteins (PBPs) has been reported as the forth mechanism of resistance to carbapenems in Gram-negative bacteria [9]. 


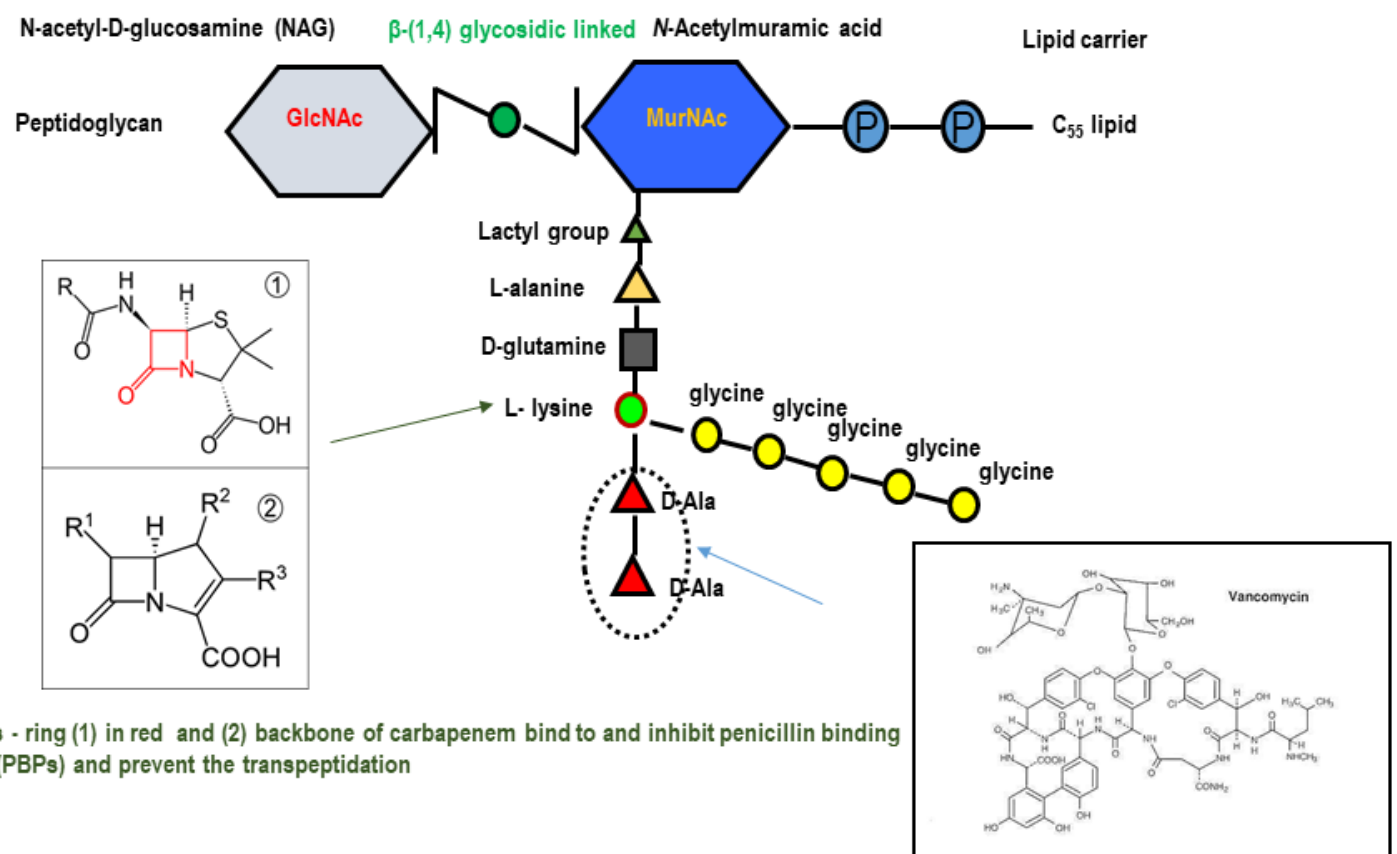

Glycopeptides (vancomycin) bind to terminal D-Ala-D-Ala residues and prevent incorporation of subunit into growing peptidoglycan

Figure 2. Mechanism of action of $\beta$-lactam antibiotics compared to that of vancomycin on the bacterial cell wall. Beta-lactams bind to and inhibit enzymes (PBPs: transpeptidases) which catalyse the final crosslinking (transpeptidation) of the nascent peptidoglycan layer which disrupt cell wall synthesis. Updated from Neu and Gootz, 1996, Ch. 11. Antimicrobial Chemotherapy in Medical Microbiology. 4th edition. Baron, editor. Galveston (TX): University of Texas Medical Branch at Galveston, USA.

Carbapenemases induce resistance essentially by hydrolysis of carbapenem using active catalytic substrates either serine or zinc [10] as indicated in Table 1. The non-metallo-carbapenemase-A (Nmc-A) was first described to cause carbapenem resistance in Enterobacteriaceae in 1993 [11]. According to the Ambler's molecular classification, class B metallo $\beta$-carbapenemases (MBL types), class A (Klebsiella pneumoniae carbapenemases (KPC) types), and class D oxacillinases (OXA types) are epidemiologically important in Enterobacteriaceae [12-14]. The genes encoding these carbapenemases can be located either on the chromosome or on mobile genetic elements (MGEs) like plasmids, integrons, and transposons $[15,16]$. The carbapenemases KPC and NDM (New Delhi metallo $\beta$-carbapenemases) producing bacteria have shown resistance against most of the $\beta$-lactams, fluoroquinolones, and aminoglycosides [17]. However, OXA type in particular OXA-48-like carbapenemases are less active against carbapenems and can induce a high resistance level only when associated with extended-spectrum $\beta$-lactamases (ESBLs) $[18,19]$. The dissemination of carbapenemases genes by MGEs among clinical isolates is a source of serious public health and food safety concerns. Enterobacteriaceae with acquired carbapenem resistance genes have been isolated from humans, animals, food, and the environment. The aim of this review is to discuss the molecular epidemiology of carbapenemases in Enterobacteriaceae. 
Table 1. Characteristics of the three most common classes of carbapenemases in Enterobacteriales.

\begin{tabular}{|c|c|c|c|c|c|c|c|c|}
\hline $\begin{array}{c}\text { Ambler } \\
\text { Class. }\end{array}$ & $\begin{array}{c}\text { Functional } \\
\text { Class }^{\text {a }}\end{array}$ & $\begin{array}{l}\text { Representative } \\
\text { Gene }^{\mathrm{b}}\end{array}$ & $\begin{array}{c}\text { No. of } \\
\text { Variants } \\
\end{array}$ & $\begin{array}{l}\text { Active } \\
\text { Site d }\end{array}$ & Substrate & Inhibitor(s) & Genetic Location & Species of Origin \\
\hline \multirow{5}{*}{ A } & \multirow{5}{*}{$2 \mathrm{~F}$} & KPC & 22 & \multirow{5}{*}{ Serine } & \multirow{5}{*}{$\begin{array}{c}\text { carbapenems, } \\
\text { cephalosporins, } \\
\text { Penicillins }\end{array}$} & \multirow{5}{*}{ Clavulanic acid } & $\begin{array}{l}\text { Chromosomally encoded; IncFIIK2, } \\
\text { IncF1A, IncI2, multiple types; Tn } 4401\end{array}$ & Klebsiella pneumoniae \\
\hline & & IMI & 9 & & & & Chromosomally encoded, $\operatorname{IncF}$ & Enterobacter cloacae \\
\hline & & SME & 5 & & & & $\begin{array}{c}\text { Chromosomally encoded, SmarGI1 } \\
\text { novel genomic island }\end{array}$ & Serratia marcescens \\
\hline & & NMC-A & 1 & & & & Chromosomally encoded & Enterobacter cloacae \\
\hline & & GES & 27 & & & & Class I integrons & Pseudomonas aeruginosa \\
\hline \multirow{10}{*}{ B } & \multirow{10}{*}{3} & NDM & 16 & \multirow{10}{*}{ Zinc } & \multirow{5}{*}{$\begin{array}{c}\text { Most } \beta \text {-lactams } \\
\text { including carbapenems }\end{array}$} & \multirow{10}{*}{ EDTA } & IncA/C, multiple; ISAba125; Tn125 & Klebsiella pneumoniae \\
\hline & & IMP & 56 & & & & $\begin{array}{l}\text { IncL/M, Inc } \mathrm{A} / \mathrm{C} \text {, multiple types; } \\
\text { class I integrons }\end{array}$ & Serratia marcescens \\
\hline & & VIM & 48 & & & & $\begin{array}{l}\text { IncN, IncI1, multiple types; } \\
\text { class I integrons }\end{array}$ & Pseudomonas aeruginosa \\
\hline & & GIM & 2 & & & & class I integrons & Pseudomonas aeruginosa \\
\hline & & SPM & 1 & & & & Plasmid-mediated & Pseudomonas aeruginosa \\
\hline & & KHM & 1 & & $\begin{array}{l}\text { Most } \beta \text {-lactams except } \\
\text { monobactams }\end{array}$ & & Plasmid-mediated & Citrobacter freundii \\
\hline & & CcrA & 1 & & \multirow{4}{*}{$\begin{array}{c}\text { Most } \beta \text {-lactams } \\
\text { including carbapenems }\end{array}$} & & Chromosomally encoded & Bacteroides fragilis \\
\hline & & BcII & 1 & & & & Plasmid-mediated & Bacillus cereus \\
\hline & & CphA & 8 & & & & Plasmid-mediated & Aeromonas hydrophilia \\
\hline & & L1 & & & & & not determined & Stenotrophomonas maltophilia \\
\hline $\mathrm{D}$ & 2 & OXA & 489 & Serine & $\begin{array}{c}\text { Most } \beta \text {-lactams } \\
\text { including carbapenems }\end{array}$ & Clavulanic acid & $\begin{array}{c}\text { IncL/M, Tn1999, IS1999, ColE } \\
\text { plasmids, Tn2013, ISEcp1, ISAba125 }\end{array}$ & Klebsiella pneumoniae \\
\hline
\end{tabular}

${ }^{a}$ cited in [12], ${ }^{\mathrm{b}}$ Most common carbapenemases identified, ${ }^{\mathrm{c}}$ Based on the Comprehensive Antibiotic Resistance Database (CARD v 3.0.2), ${ }^{\mathrm{d}}$ Carbapenemases induce resistance essentially

by hydrolysis of carbapenem using active catalytic substrates either serine or zinc. 


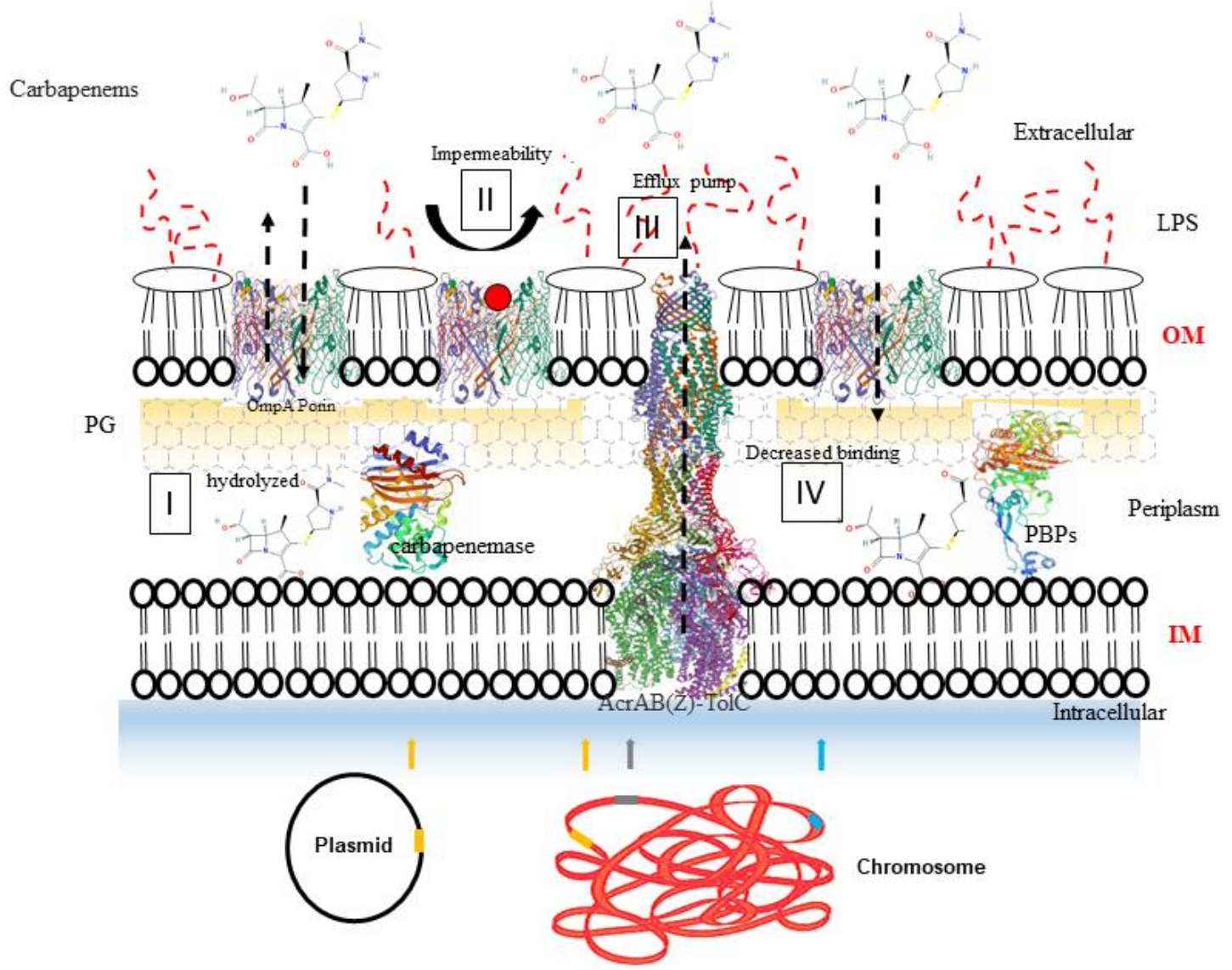

Figure 3. Major mechanisms associated with carbapenem-resistance in Gram-negative bacteria. (I) Production of carbapenemases enzyme from gene located on chromosome or plasmid that hydrolyze carbapenem antibiotics shown in golden rectangles. (II) Decreased permeability of the outer membrane due to structural mutations in porins (modified porins shown as red circle). (III) Drug efflux pumps. The blue and grey rectangles represent the chromosomal loci that encode various membrane associated proteins. Abbreviations: LPS, lipopolysaccharides; OM, outer membrane; IM, inner membrane; PG, peptidoglycan.

\section{Carbapenemases-Producing Enterobacteriaceae from Humans}

The $\beta$-lactams antibiotics such as penicillins and cephalosporins have been wildly used against pathogenic Enterobacteriaceae because of their broad-spectrum activity [20]. However, this practice contributed to the emergence and spread of several types of $\beta$-lactamases including ESBLs. To overcome the resistance against extended spectrum cephalosporins (ESC) and cephamycins in Enterobacteriaceae, carbapenems have been introduced in human medicines. According to the recent 2020 Canadian Antimicrobial Resistance Surveillance System (CARSS) annual report, the carbapenems use in human medicine has been increased from 3.0 to 6.8 defined daily doses (DDDs) per 1000 inhabitants between 2014 and 2018 in Canada. Consequently, a concomitant nine-fold increase in the number of patients colonized by carbapenemases-producing organisms (CROs) without signs of infection has been reported in Canada [20]. Globally, the population of CRE is increasing dramatically [21,22]. There could be several factors leading to the spread of carbapenemase-producing pathogens in humans. These factors include continuous exposure to antibiotics, usage of different concentrations of antibiotics, and contamination of surgical equipment used [12,23,24].

The prevalence of carbapenem-producing Enterobacteriaceae (CPE) is high in humans with advanced age, primarily, due to their frequent visits to hospitals, long-term stay in health care facilities, tertiary care hospitals, and teaching hospitals [25-30]. Hospital stay represents a particularly high risk to be colonize or in developing an infection with a CRE. Recent studies found that CRE colonization among 
ICU patients showing new emerging mechanisms of resistance continue to rise in the United States of America [31,32]. There seems to have no different in other developed countries. For instance, Canada's Nosocomial Infection Surveillance Program data suggested that incidences of $b l a_{\mathrm{NDM}}, b l a_{\mathrm{KPC}}, b l a_{\mathrm{OXA}-48}$, and bla $a_{\text {VIM }}$ producing K. pneumoniae and Enterobacter spp. increased significantly in Canadian health care facilities since 2007 [33]. These health care facilities could be a reservoir for patient spreading $\mathrm{CPE}$ to multiple regions. For instance, $b l a_{\mathrm{KPC}}$-producing $K$. pneumonia have been reported in hospital outbreaks in many European countries such as Greece, Italy, Spain, France and Germany [3,34-40]. A recent study reported cases of $b l a_{\mathrm{NDM}-1}$ and $b l a_{\mathrm{KPC}-2}$-producing K. pneumonia among transplanted patients in Brazil [41]. Although, little is known about the spread and clinical relevance of CRE in Africa, two studies reported their prevalence in hospital and community settings among several African countries [42,43]. Issues about carbapenemases include their potential link with multidrug-resistance genes on the same MGEs. For instance, the $b l_{\mathrm{KPC}}$ gene encoding KPC enzyme to hydrolyze all $\beta$-lactams was found on plasmids carrying multiple other antimicrobial resistance determinants $[44,45]$. Outbreaks caused by multidrug resistant and $b l a_{\mathrm{KPC}}$-positive K. pneumoniae opportunistic pathogenic strains have been reported in North America, Europe, Asia and South America [3,46-48]. A recent study from China reported a Morganella morganii isolate, an opportunistic pathogen, harboring $b l a_{\mathrm{NDM}-5}$ gene on a self-transmissible IncX3 plasmid from a stool sample of a cancer patient [49].

Another important factor responsible for worldwide dissemination of CRE is the international travelling and medical tourism. There are several reports demonstrating the role of travelling to affected developed countries in the epidemiology of CRE. Pathogenic strains of K. pneumoniae and Enterobacter cloacae containing $b l a_{\mathrm{KPC}}$ have been isolated from patients from France and Greece hospitalized in New York [50,51]. Overcrowding coupled with poor sanitation conditions including inappropriate waste management system and misuse of antibiotics could play roles in the spread of antimicrobial resistance genes in general and those for carbapenemases in particular. Furthermore, urbanization and globalization are greatly involved in spreading antimicrobial resistance pathogens all over the world.

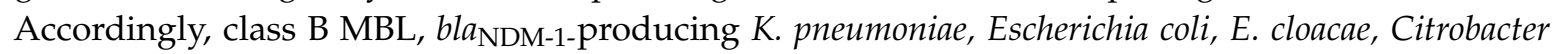
spp., Proteus spp., and Klebsiella oxytoca strains were originally isolated in India. These same bla $a_{\mathrm{NDM}-1}$ producing K. pneumoniae and E. coli strains were subsequently isolated from Sweden and UK patients who had travelled to India recently. The patients in Sweden and UK may either have been hospitalized or underwent any medical intervention in India which could led to their infection or colonization by these pathogenic strains producing $b l a_{\mathrm{NDM}-1}$ [52-54]. A similar scenario has been reported in Canada and the United States where bla $a_{\mathrm{NDM}-1}$-producing Enterobacteriaceae were isolated from patients who visited and received medical cares in the Indian subcontinent $[55,56]$. Furthermore, a recent study reported two hyper-virulent K. pneumoniae clones of ST86 harboring plasmid mediated bla $a_{\mathrm{KPC}-2 \text {, }}$ isolated from a Canadian patient who visited Greece [57]. Likewise, a novel $b l a_{\mathrm{KPC}-3}$ variant $\left(b l a_{\mathrm{KPC}-50}\right)$ was recently identified in multi-drug resistant $K$. pneumoniae clinical isolate conferring resistance to ceftazidime-avibactam in Switzerland that was most likely acquired in Greece [58]. Several studies have demonstrated that medical tourism is another way to introduce CREs from an endemic country to a non-endemic country [59-61]. For instance, a case has been reported in an Israelis hospital where four non-Israelis patients, were positive for bla $a_{\mathrm{OXA}} 48$-producing Enterobacteriaceae [61]. The OXA-48 positive bacteria were absent from this hospital before these patients' admission in the Israel, two and one of

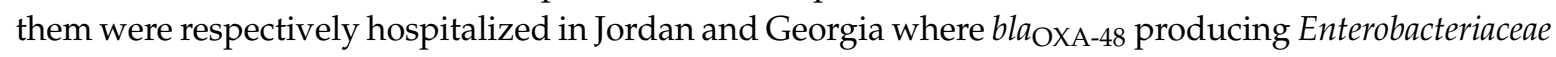
were prevalent, demonstrating thus the role of medical tourism in the epidemiology of CRE [60].

\section{Companion Animals}

Carbapenems are not licensed for the treatment of infectious diseases in companion animals in most of countries. As a result, pathogenic strains of Enterobacteriaceae causing infections in companion animals are not usually screened for carbapenemase resistance genes in veterinary laboratories. The possible way companion animals may get infected with CRE is through direct contact with colonized hosts and contaminated environment. Eventually, companion animal may become a 
reservoir for CPE [62-65]. For instance, a bla $\mathrm{OXA}-48$ carbapenemase-producing K. pneumoniae has been transmitted from human to companion animals (dogs) through contaminated hands [66]. In 2015, the transmission of an IncX3 plasmid bearing bla $a_{\mathrm{NDM}-5}$ in E. coli ST167 was detected in dogs and humans in Finland [67]. A recent study found IncX3 plasmid mediated bla $a_{\mathrm{NDM}-5}$ in E. coli ST410 in four Korean dogs implying the HGT an important mechanism of their spread among companion animals. Carbapenemase-producing E. coli ST131 has also been reported repeatedly in both household members and their companion animals [68-70]. An Australian study also reported the IncHI2 type plasmid bearing $b l a_{\mathrm{IMP}-4}$ in Salmonella Typhimurium isolates from infected cats [71]. Importantly this variant showed sequence similarity to two bla $a_{\mathrm{IMP}-8}$ carrying IncHI2 plasmids from Enterobacter spp. from humans with an indication of nosocomial spread and broader risk to humans, animals and the environment. Enterobacteriaceae producing carbapenemase ( $b l a_{\mathrm{NDM}-1}$ and $\left.b l a_{\mathrm{OXA}-48}\right)$ have been isolated from companion animals like dogs, cats, and horses in the USA, Germany, Greece and UK [66,72-75]. Another recent study in Switzerland reported the isolation of various carbapenemase-producing Enterobacteriales in companion animal clinics mainly associated with poor clinical practices [76]. The isolation of CRE in companion animals brings the attention to reconsider the use of any off-label use of carbapenems in the veterinary medicines. Even carbapenems are not registered to use in companion animals, these antibiotic are used as off-label for the treatment of urinary tract infections in dogs and horses and to treat after surgical procedure infections caused by multidrug resistance E. coli in the UK and some other European union countries [77]. Identification of CPE in companion animals could become significant for public health due to not only host-to-host transmission but also possible gene transfers between commensals and pathogens. Due to selection pressure, treated animals (pets) may become colonized with CPE that could be transmitted to human through fecal - oral contaminations.

\section{Carbapenemases-Producing Enterobacteriaceae in Other Animals}

Carbapenemases-producing Enterobacteriaceae is not only a threat to humans; but animals may also get colonized and/or affected by CPE. The CPE could be isolated from food producing animals such as chicken, swine and cattle. A geographical distribution of CPE isolates from animal clinical samples has been recently reported [9].

\section{Food Producing Animals}

Various studies reported the presence of CPE in livestock which could constitute a food safety issue. Based on these studies, $b l a_{\mathrm{VIM}-1}$ and $b l a_{\mathrm{NDM}-1}$ were the most prevalent carbapenemase enzymes among Enterobacteriaceae in food producing animals [78-82]. In Germany, bla $a_{\mathrm{VIM}-1}$ producing S. enterica and $E$. coli have been isolated from swine and chicken farms. In both cases, $b l a_{\mathrm{VIM}-1}$ gene was located on an IncHI2 type plasmid. These isolates showed multidrug resistance due to the presence of other resistance genes including $b l a_{\mathrm{ACC}-1}, b l a_{\mathrm{ADD}-1}$ and $s t r \mathrm{~A} / \mathrm{B}$ in addition to the $b l a_{\mathrm{VIM}-1}$ on same IncHI2 type plasmids $[80,81]$. Apart from $b l a_{\mathrm{VIM}-1}$, three E. coli isolates were found to carry the $b l a_{\mathrm{NDM}-5}$ gene on a IncX3 transferrable plasmid, including one co-harboring the colistin resistance $m c r-1$ gene on IncHI2 plasmid of ST446 and the other two belonged to ST2, isolated from three dairy cows in China [83]. Moreover, a novel IncX3-type plasmid harboring a bla $a_{\mathrm{NDM}}$ variant $\left(b l a_{\mathrm{NDM}-20}\right)$ due to three point mutations compared to bla $a_{\mathrm{NDM}-1}$, was recovered recently in an E. coli ST1114 from swine in China thus, suggesting that food-animal could be a source of new carbapenemase genes [84].

\section{Carbapenemases Producing Enterobacteriaceae in Food}

CREs from food-producing animals could find their way into the food chain, leading to an alarming food safety issue. For public health concerns with respect to risk of transfer to humans via the food source, several resistance surveillance systems for retail meat are in place which include carbapenem susceptibility monitoring in many countries. Interestingly, CRO could be isolated from the food that escape resistance surveillance programs such as seafood [85]. Besides live animals, several reports demonstrating the spread of CPE in retail meat in Egypt, China and Pakistan [86-88]. 
As reported in 2016 in China, the increasing spread of carbapenem and colistin-resistant E. coli clone ST167 from chicken meat harboring $b l a_{\mathrm{NDM}-9}$ and $m c r-1$ co-located on a plasmids has raised concerns worldwide because of potential transfer of this resistance plasmids to other Gram-negative pathogens and to other countries [88]. Moreover, VIM-1 producing S. enterica serovar Infantis have been isolated from minced pork meats in Germany [89] and NDM-1 producing S. enterica serovar Indiana have been isolated from chicken carcasses in China [90]. Additionally, a recent study reported the contamination of retail meat samples from pork, chicken and beef with E. coli and K. pneumonia containing bla $a_{\mathrm{NDM}}$ genes located on IncX3 plasmid [91]. Between 2016 to 2018, a substantial increase of such CRE from $9.4 \%$ to $22.2 \%$ in the retail meat samples was reported.

As stated above CRE could be found in seafood as reported as VIM-1 producing E. coli from retail squid, sea squirt, clams and seafood medley in Germany, China and Korea [92]. Trading of seafood from endemic countries to non-endemic countries could result in the spread of carbapenem resistance genes. For instance, the Canadian Integrated Program for Antimicrobial Resistance Surveillance (CIPARS) reported carbapenem-resistant Enterobacter spp. in fresh and frozen raw shrimp collected imported from Southeast Asia to Canada [93]. A recent study from Netherlands reported the isolation of E. cloacae ST813 bearing plasmid with bla $a_{\mathrm{IMI}-2}$ and a novel Ambler class A carbapenemases $b l a_{\mathrm{FLC}-1}$ from a frozen vannamei white shrimp (Litopenaeus vannamei) originating in India. This new bla $a_{\mathrm{FLC}-1}$ carbapenemases was found to be related to previously known French imipenemase (FRI), with $82 \%$ amino acid identity to $b l a_{\mathrm{FRI}-1}$ and $87 \%$ to $b l a_{\mathrm{FRI}-5}$ [94]. Although rare but raw milk containing OXA-48-producing K. pneumoniae ST530, an epidemic clone, was reported in Lebanon [95].

A role for fresh produces in spreading antimicrobial-resistant has been suggested by several studies. In China, fresh lettuce was found to be contaminated with E. coli ST877 co-producing NDM-1 and KPC-2, while also carrying fos $A 3$ and floR genes on a transferrable IncA/C2 type plasmid [96]. Various species of CRE were recovered from leek, radish, basil, spinach, lettuce, traditional and commercial salads in Iran and OXA-48 producing K. pneumonia were detected in fresh vegetables from Algeria [97]. It has also been suggested that international trade of fresh vegetables and spices could be the possible route for the spread of CRE. Coriander imported from Asia to Switzerland and many

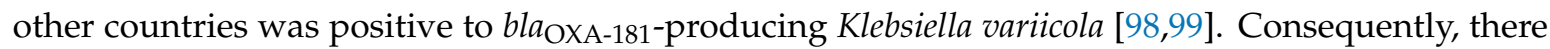
is a need for resistance surveillance programs for both carbapenemase-producing pathogenic and non-pathogenic organisms in the food chain to find the potential reservoirs of carbapenemase genes and to prevent their spread from food to humans.

\section{Carbapenemases-Producing Enterobacteriaceae from the Environment}

As discussed above, several studies demonstrate the spread of CPE all around the world among humans and animals. However, there are very few reports on the role of environmental contamination in the spread of CPE. The environment, surrounded by the CPE carriers, may be contaminated with these bacteria and further act as a vector for their dissemination. Dissemination of environmental CPE (eCPE) can negatively impact human health [100]. The prevalence rate of eCPE is high especially around intensive care units, acute and long-term health care facilities. Exposure of health care personnel to infected patients and cleaning methods used in the health facilities could potentially be responsible for dissemination of eCPE [101]. A study reported the presence of eCPE on the bed surface, personal table and infusion pump used by one CPE-infected patient [101]. The potential presence of eCPE on health care personnel brings attention toward the importance of adopting cleaning methods used in hospitals to disinfect the surfaces and material used by CPE carriers [102]. In hospitals, carbapenems are frequently used to treat infectious diseases caused by extended spectrum cephalosporinase (ESC) producing bacteria. Carbapenems are not entirely metabolized in the body and some residues present in human excreta can get into hospital sewage. Due to selection pressure, there is a chance that pathogens present in hospital effluent may become resistant against carbapenems. It has been reported that hospital sewage may act as a reservoir for resistance genes and a point where organisms likely acquire resistance through horizontal gene transfer events [103]. For instance, NDM-4 
producing E. coli with downstream bleomycin resistance gene, ble $e_{\mathrm{MBL}}$ on a plasmid type associated with complete IS Aba125 were isolated from hospital sewage in India, suggesting hospital wastes as major reservoir of resistance genes [104]. Likewise, antibiotic residues released into the municipal wastewater along with human excreta could contribute to selection of CPE the ground and surface water sources. A VIM-1-producing resistant K. pneumoniae strain has been isolated from rivers in Spain, Switzerland and Sweden [105-107]. The presence of CRE in wastewater is a potential concern because this environment may serve as major reservoir leading to HGT events and an increased risk of carbapenem resistance spreading into the environment. The data collected from a recent US survey of seven wastewater treatment plants reported the detection of $20 \%$ carbapenem-resistant $E$. coli isolates of sequence types associated with extra-intestinal infections in humans harboring predominantly $b l a_{\mathrm{VIM}}$ and $b l a_{\mathrm{KPC}}$ genes [108]. Similarly, a study from the United States documented the presence of CRE including E. coli and P. mirabilis isolates harboring bla $a_{\mathrm{IMP}-27}$ gene on IncQ1 plasmids in both environmental and fecal samples of swine production system [109]. The presence of $b l a_{\mathrm{KPC}-2}$ gene has been reported in the United States in the metagenome from the feces of beef cattle regardless of antibiotic use in the farm [110]. Moreover, two most recent studies reported the presence and survival of carbapenem-resistant organisms harboring a plasmid-borne bla OXA-23 gene from swine manure environment from a Croatian pig farm and NDM-5 producing E. coli ST156 from a poultry farm in China. These suggest the possible dissemination of CRE in the food chain through animal manure fertilization [111,112]. On the other hand, irrigation water and various water matrices are also considered as major source of fresh produce contamination with resistant bacteria including CRE that can potentially be transferred to the consumer especially when consumed raw [113]. Likewise, a recent study reported carbapenem resistant K. pneumoniae isolates from Austrian rivers showing genetic similarities to clinical isolates from hospitals raises concerns regarding the role of surface water in the of dissemination of CRE [114]. Surprisingly, tap water could serve as reservoir of community exposure to CRE in high income countries. A recent multi-state study form United States screened drinking water samples from both public and private water systems in six states and detected 6.4\% CRE

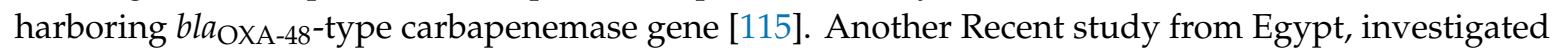
the occurrence of $\beta$-lactamase and CRE in the integrated agriculture-aquaculture environment and isolated several Enterobacteriaceae strains resistant carrying predominantly the carbapenemase resistant gene $b l a_{\mathrm{KPC}}$ either alone or with the $\beta$-lactamase genes $\left(b l a_{\mathrm{CTX}-\mathrm{M}-15}, b l a_{\mathrm{SHV}}, b l a_{\mathrm{TEM}}\right.$, and $\left.b l a_{\mathrm{PER}-1}\right)$. This study suggests transmission of the resistance genes among Enterobacteriaceae strains in integrated agriculture-aquaculture system with serious public health implication [116].

\section{Molecular Epidemiology of Carbapenem Resistance (CR) Genes}

Spread of CRE: The most frequently identified carbapenem genes are the ambler class A including $b l a_{\mathrm{KPC}}$ followed by class B metallo- beta lactamases (MLBs) such as bla $a_{\mathrm{NDM}}$, and the class D OXA-type gene like $b l a_{\mathrm{OXA}-48}$ (Table 1). Since its identification in the North Carolina, USA in 1996, in K. pneumonia patient, the epidemiology of bla KPC producing isolates has expanded mostly globally in Africa, America, Asia, Australia, and Europe especially the clonal group (CG) 258, which includes the lineages ST258 and ST11). Since 2015, several outbreaks related to ST258 have been documented in hospital of Israel closely related to strain found in New York [117]. Likewise, the class B metallo- beta lactamases genes, including $b l a_{\mathrm{NDM}}, b l a_{\mathrm{SME}}, b l a_{\mathrm{GES}}, b l a_{\mathrm{VIM}}$, and $b l a_{\mathrm{IMP}}$, have also been disseminated worldwide, $b l a_{\mathrm{NDM}-1}$ being the most prevalent worldwide [118]. The gene bla $a_{\mathrm{NDM}-1}$ was first detected in a K. pneumonia isolate from a Swedish patient of Indian origin in 2008 in a multidrug-resistant K. pneumoniae, suffering from urinary tract infection acquired in India [119]. Subsequently, the bla $a_{\mathrm{NDM}-1}$ was also found in $K$. pneumonia isolate from Croatia, from a patient arrived from Bosnia and Herzegovina. The second geographical origin of bla $a_{\mathrm{NDM}-1}$ considered to be eastern Balkans. In May 2010, a case of infection with $b l a_{\mathrm{NDM}-1}$ producing E. coli was reported in Coventry in the United Kingdom. Moreover, the $b l a_{\mathrm{NDM}-1}$ gene was also reported in Australia, Austria, Belgium, China, Canada, France, Germany, Hong Kong, Japan, Netherland, Norway, and Sweden. Likewise, the bla $a_{\mathrm{SME}}$ were reported in England with sporadic 
reports of such gene in USA. Since 2004 and it has also been reported in Argentina, Australia, Brazil, Canada and Switzerland but the increasing number of this gene have been reported in America and UK [120]. The bla VIM gene was originally described in Italian Pseudomonas aeruginosa in the mid-1990s and afterwards CRE carrying bla $\mathrm{VIM}$ were predominantly reported in Europe and large number of cases were also reported in other countries including Africa, Taiwan, Mexico, Saudi Arabia and the United States. However, the bla $a_{\mathrm{VIM}}$ gene was found in Greece with more than 48 variants of this gene showing global dissemination [121]. Furthermore, the bla $a_{\mathrm{IMP}}$ gene was first originated in south pacific Asia predominantly among isolates of E. coli and Enterobacter on class 1 integrons and genomic evidences are now emerging of its dissemination globally [122]. Finally, among the various variants known of Class D today, the bla $a_{\mathrm{OXA}} 48$ gene was first identified in Turkey in 2001. Although endemic during that time mostly in Turkey and Malta but since 2015, it has been spread to multiple countries including Singapore, Algeria, Korea, south Africa and have recently emerged in Canada and other western countries.

CRE carriage: Several studies particularly in China and also around the globe have recently attempted to investigate the carriage of CRE in animals and humans that possibly contributes to its dissemination in societies and healthcare facilities [123,124]. For instance, a recent case study in Singapore determined the duration of CRE carriage among various hospital workers by investigating 21 CRE carriers for more than 1 year. The authors of this study reported a mean carriage duration of 86 days among hospital workers and further suggested that the prolonged carriage could be associated with use of antimicrobial drugs and the probability of decolonization in a year was 98.5\% [124]. Despite reports in healthcare facilities, a recent study by Zhai, et al. [125] monitored the carriage of CRE in a Chinese poultry farm for over a year (January 2017 to April 2018). During this period these authors collected 350 cloacal samples from four broiler farms in additional to 582 environmental samples and found that CRE negative 1-day-old broilers acquired bla $a_{\mathrm{NDM}}$ within $24 \mathrm{~h}$ of transfer. Furthermore, the same study also analyzed the persistence and transmission of $b l a_{\mathrm{NDM}}$-producing bacteria in a Chinese poultry farm and found that the IncX3 plasmid accounts for $71 \%$ of $b l a_{\mathrm{NDM}}$ carriage that persisted in farm over 16 months and about $20 \%$ also carried either the colistin resistance $m c r-1$ or $m c r-8$ gene. This study further suggests that the contaminated in-house environment contributes to the persistence and transmission of $b l a_{\text {NDM }}$ producing bacteria in Chinese poultry farms.

Food chain transmission: The rise of CRE in food-producing animals and food supply is of growing concern globally and, given the risks of CRE to human health, there have been a zero-tolerance policy and an international ban on the sale of food items contaminated with CRE in several countries [126]. Therefore, prevention of CRE occurrence and spread in food-producing, wildlife and companion animals is a major public health priority to protect both persons with direct exposure and consumers. Authorities in European countries have already reacted by establishing active carbapenem resistance surveillance programs targeting food-producing animals mainly poultry, pork, cattle, and retail meat products [127]. There is concern that without these programs the presence of carbapenem genes in bacteria has the potential to enter the food supply undetected and subsequently transmission to humans [19]. For example, in 2014 a study by Morrison and Rubin [85], reported a $3.94 \%$ prevalence of CPOs in seafood imported in Canada that could pose a potential risk for transfer to clinically relevant bacteria and eventually to humans which is certainly of concerns. Strong evidences exist that the transmission of resistance might have taken place from animals to humans. Although many of these evidences were not direct and were based on the similarities between the carbapenem resistance genes of bacteria isolated from food-producing animals including poultry, pigs, cattle and from humans having close contact with these animals such as farm workers, animal caretakers and their family members [128]. To support risk assessment for zoonotic CRE, a comprehensive systematic review on CRE that carried $b l a_{\mathrm{VIM}}, b l a_{\mathrm{KPC}}, b l a_{\mathrm{NDM}}, b l a I M P$ and $b l a_{\mathrm{OXA}}$, from wildlife, food-producing, and companion animals was conducted recently by Köck, el al [72]. This study was primarily focused on the dissemination of CRE in livestock, food items including seafood, companion animals and their potential of transmission to exposed humans. The most prevalent carbapenem genes were $b l a_{\mathrm{VIM}}, b l a_{\mathrm{KPC}}$, 
$b l a_{\mathrm{NDM}}, b l a_{\mathrm{OXA}}$, and blaIMP in E. coli and K. pneumoniae isolates. Interestingly, only two independent studies reported that 33-67\% of exposed humans on poultry farms carried CRE closely related to isolates from the poultry farm environment suggesting fecal-oral transmission or transmission via the food sources has the higher potential to spread CREs to healthier population. Wang, et al. tested six fecal specimens from farmers and workers from a Chinese commercial chicken farm, of which three (50\%) were positive for plasmid-borne $b l a_{\mathrm{NDM}-5}$ producing E. coli and demonstrated that two of the farmers isolates shared sequence types (ST10, ST746) with isolates from local dogs, flies, and chickens and clustered closely together, suggesting exposure and transmission to human on the farm environment. In their follow up study, Wang et al. [129] demonstrated clonal commonality between bla $a_{\mathrm{NDM}}$-positive E. coli isolates from chicken farms, slaughterhouses, supermarkets, and humans, belonging to sequence types ST10 and ST156. Recently, another study in Egypt by Elshafiee et al. [130] provided strong evidences of direct transmission of CRE to humans from farm animals. Another study by Li et al. [124], investigated the prevalence, risk factors, and drivers of CRE transmission between humans and their backyard animals in rural China that provided direct evidence of inter-host transmission of $b l a_{\mathrm{NDM}}$ producing E. coli between humans and backyard animals. Moreover, the incidence of carbapenem resistant genes in food-producing animals has also been reported from several other countries with chickens and pig being the most investigated species, in which carbapenem resistant genes has been most frequently detected [128].

Detection of CRE: In the recent past, several molecular genotyping methods such as microarrays, single and multiplex polymerase chain reaction (PCR) assays have been used to detect the common carbapenemases, including $b l a_{\mathrm{KPC}}, b l a_{\mathrm{NDM}}, b l a_{\mathrm{IMP}}, b l a_{\mathrm{VIM}}$ and $b l a_{\mathrm{OXA}-48}$, in bacterial isolates or directly from clinical specimens [131]. However, these molecular methods can accurately detect specific carbapenemase genes but cannot detect novel carbapenemase genes. On the other hand, whole genome sequencing (WGS) is a powerful new method with vastly improved resolution over current gold-standard techniques that not only identifying CRE but also providing detailed insights into their evolution and dissemination [132]. WGS potentially represent the ultimate molecular detection by probing the complete genomic content, chromosomal and extrachromosomal, of bacteria for the detection of carbapenem resistant genes. Moreover, WGS provide an opportunity to extrapolate additional information, including strain relatedness, molecular epidemiology, plasmids of replicon types harboring the carbapenemase, prediction of factors influencing carbapenem resistance for example point mutation and presence of other resistance factors and data can be analyzed in real-time or stored for future analysis. There is no doubt that WGS enhances our ability to characterize and resolve outbreaks of carbapenem resistant bacterial populations, understand and predict epidemiological trends, and create new machine learning tools for rapid detection of novel variants. As new algorithms are developing for tracking of transmission of carbapenem resistant bacteria in various fields including health care facilities and agricultural products (poultry, beef, and pork), likely to become increasing efficient and interpreting with the level of precision necessary to guide the modification of infection control procedures and food safety measures to limit the spread of CPO, allowing WGS to gain broader acceptance [133].

Role of insertion sequences, transposons and integrons: Dissemination of CPE among humans and animals has been enhanced by the horizontal transfer of CR genes on MGEs such as insertion sequences, transposons and integrons and their associated plasmids. [16,50,134-137]. The genetic analysis of $b l a_{\mathrm{IMP}}$ and $b l a_{\mathrm{IVIM}}$ from endemic areas in Southern Europe and Southeast Asia showed an association between both genes with class 1 integrons [138]. Molecular typing method such as PCR based replicon typing and plasmid multi-locus sequence typing (pMLST) methods have been used to identify a range of plasmid incompatibility groups responsible for the epidemiology of CR genes [139-141]. Most of the CR genes associated with the Ambler class A, class B, and Class

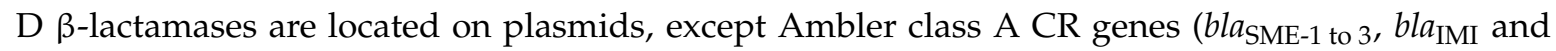
$\left.b l a_{\mathrm{NMC}-\mathrm{A}}\right)$, which are usually located on the chromosome (Table 1). Some bla $a_{\mathrm{KPC}}, b l a_{\mathrm{VIM}}, b l a_{\mathrm{IMP}}$, and $b l a_{\mathrm{OXA}}$ type carbapenemases genes have been located within transposons on plasmids which are 
responsible for the spread of such $\mathrm{CR}$ genes among Enterobacteriaceae. In addition, clonal expansion also acts as a way to spread the CR genes as described for $b l a_{\mathrm{KPC}}$ in K. pneumoniae ST258 [142] and $b l a_{\mathrm{NDM}-5}$ in E. coli on the IncX3 type plasmid [143]. The insertion sequences and transposons play a role in the genetic variability. Accordingly, IS $A b a 1 / 3$ and IS $A b a 125$ have been reported to induce expression of several carbapenem resistance genes such as bla $a_{\mathrm{OXA}-23-51-66}$-like and $b_{\mathrm{NDM}-1}$ in $A$. baumannii and K. pneumoniae [144-148]. Similarly, a novel Tn4401 transposon variant ( $\operatorname{Tn} 4401 \mathrm{~h}$, a188-bp deletion) on conjugative plasmids has been associated with enhanced bla $a_{\mathrm{KPC}}$ expression and the degree of phenotypic resistance to carbapenemases in K. pneumoniae [149].

Plasmid: Plasmids belonging to different incompatibility groups play an important role in the epidemiology of CR genes. Plasmid-mediated spread of bla $a_{\mathrm{NDM}-1}$ gene in Enterobacteriaceae has attracted attention, primarily, due to its predominant presence in nosocomial isolates (K. pneumoniae), as well as in community-acquired isolates (E. coli). Another characteristic is the propensity of conjugative plasmids to transfer resistant genes among other Enterobacteriaceae $[150,151]$. The bla ${ }_{\mathrm{NDM}-1}$ gene was first detected in New Delhi, and in the Indian subcontinents [52]. Since then it has been isolated in UK, Pakistan, Bangladesh, Central and South America, the US and Canada [151]. In this case, urbanization and international travelling were described to contribute in the propagation of the bacterial clones and plasmids with $b l a_{\mathrm{NDM}-1}$ gene from Indian subcontinent to other countries and continents [151]. Genetic studies demonstrated that the $b l a_{\mathrm{NDM}-1}$ gene was associated with different bacterial clones and has spread among Enterobacteriaceae and non-Enterobacteriaceae species. This bla $a_{\mathrm{NDM}-1}$ gene is carried by a broad range of multidrug plasmids belonging to the $\operatorname{Inc\mathrm {A}} / \mathrm{C}, \operatorname{IncL} / \mathrm{M}, \operatorname{IncN}$ and $\operatorname{Inc} \mathrm{F}$ incompatibility groups [45]. These plasmids with $b l a_{\mathrm{NDM}-1}$ gene, also harbor other genes conferring resistance to aminoglycosides, quinolones, trimethoprim, sulphonamides, tetracyclines, colistin and heavy metal $[3,44,152,153]$. Moreover, bla NDM-1 $_{1}$ has been identified in E. coli ST90, ST131 and E. cloacae ST231 whereas $b l a_{\text {NDM-5 }}$ gene in ST101, ST167, and ST405 clones bearing diverse transmitting vectors were responsible for community acquired infections [154,155]. Thus, infections caused by NDM pathogens could be difficult to be treated [52,156,157].

Some CR genes including $b l a_{\mathrm{OXA}-48}$ are associated with a single type of plasmid incompatibility group in Enterobacteriaceae [39,158]. The dissemination of bla $a_{\mathrm{OXA}-48}$ gene among K. pneumoniae, E. coli and E. cloacae is due to the presence of this gene on mono-drug resistance plasmids belonging to the IncL/M incompatibility group sharing common characteristics such as self-transferability, no additional antibiotic resistance genes and size of plasmid range between $60-70 \mathrm{kbp}$ [45]. In companion animals, the $b l a_{\mathrm{OXA}-48}$ gene was found to be located on a multidrug-resistance plasmids belong to same IncL/M incompatibility group also carrying and extended spectrum $\beta$-lactamases and Amp C $\beta$-lactamases $[45,66,159]$.

The $b l a_{\text {KPC }}$ genes have usually been located on self-transferable and multidrug-resistant large size plasmids, which are varying in size as well as phage-like plasmids $[160,161]$. The transferability of the bla $a_{\mathrm{KPC}}$ plasmids has been reported between $C$. freundii and $K$. oxytoca belonging to two different bacterial genera $[162,163]$. These plasmids also carry additional antibiotic resistance genes for aminoglycosides, ESBLs and fluoroquinolones [164]. Different K. pneumoniae clones and different strains may carry KPC $\beta$-lactamase. In all reported cases, the $b a_{\mathrm{KPC}}$ gene has been associated with the Tn 3 type transposon named Tn4401. This transposon may be a major source for transmission of bla $a_{\mathrm{KPC}}$ gene [160].

\section{Conclusions}

The driving factor for the continuous increase in antibiotic resistance is antimicrobial usage in human and veterinary medicine as well as in agriculture. The European Surveillance of Antibiotic Consumption Network data in 2017 reported that in 10 out of 25 countries, consumption of carbapenems among humans increased since 2012, while only one country (Portugal) showed a decreasing trend during the same period (https://ecdc.europa.eu/en/publications-data/summary-latest-data-antibioticconsumption-eu-2017). The carbapenems resistance in addition to ESC and cephamycins resistance in Enterobacteriaceae represent an important threat for public health. Out of the three classes, the class A 
carbapenemases KPC has spread globally and become more prevalent in the USA and Greece. The class B carbapenemase VIM and IMP has also been reported worldwide, but seem more endemic in Taiwan, Japan, and some European countries. The carbapenemase KPC, IMP, VIM, NDM, and OXA types have been mainly reported in nosocomial K. pneumonia strains. Pathogenic E. coli strains carrying $b l a_{\mathrm{NDM}-1}$ and $b l a_{\mathrm{OXA}-48}$ genes also have been found in community acquired infections. Therefore, proper identification and surveillance programs of carbapenem resistance pathogens and non-pathogenic strains have become necessary to support the control of CRE infections in both animals and humans. Source attribution studies along with developing alternative infection control strategies are warranted.

Author Contributions: M.S.D. (principle investigator) and P.B. conceptualized the study design; G.T. and M.A.R. wrote the review with major contributions from M.S.D. and P.B.; M.S.D. provided overall guidance, mentorship, and resources throughout the scope of this review. All authors have read and agreed to the published version of the manuscript.

Funding: This work was supported by Agriculture and Agri-Food Canada to M.S.D. through A-Base project \#2411 and the Genomic Research and Development Initiative on AMR (GRDI-AMR) mitigation project.

Conflicts of Interest: The authors declared no conflict of interest.

\section{References}

1. WHO. World Health Organization. Gloval Priority List of Antiviotic-Resistand Bacteria to Guide Research, Discovery, and Development of New Antibiotics; WHO: Geneva, Switzerland, 2017.

2. Adeolu, M.; Alnajar, S.; Naushad, S.; Gupta, R.S. Genome-based phylogeny and taxonomy of the 'Enterobacteriales': Proposal for Enterobacterales ord. nov. divided into the families Enterobacteriaceae, Erwiniaceae fam. nov., Pectobacteriaceae fam. nov., Yersiniaceae fam. nov., Hafniaceae fam. nov., Morganellaceae fam. nov., and Budviciaceae fam. nov. Int. J. Syst. Evol. Microbiol. 2016, 66, 5575-5599. [CrossRef] [PubMed]

3. Nordmann, P.; Naas, T.; Poirel, L. Global spread of Carbapenemase-producing Enterobacteriaceae. Emerg. Infect. Dis. 2011, 17, 1791-1798. [CrossRef] [PubMed]

4. Kumar, M. Colistin and tigecycline resistance in Carbapenem-resistant Enterobacteriaceae: Checkmate to our last line of defense. Infect. Control. Hosp. Epidemiol. 2016, 37, 624-625. [CrossRef] [PubMed]

5. Sheu, C.-C.; Chang, Y.-T.; Lin, S.-Y.; Chen, Y.-H.; Hsueh, P.-R. Infections caused by Carbapenem-resistant Enterobacteriaceae: An update on therapeutic options. Front. Microbiol. 2019, 10, 80. [CrossRef]

6. Papp-Wallace, K.M.; Endimiani, A.; Taracila, M.A.; Bonomo, R.A. Carbapenems: Past, present, and future. Antimicrob. Agents Chemother. 2011, 55, 4943-4960. [CrossRef]

7. Kumar, P. Pharmacology of specific drug groups. In Pharmacology and Therapeutics for Dentistry; Dowd, F.J., Johnson, B.S., Mariotti, A.J., Eds.; Elsevier: Milton, ON, Canada, 2017; pp. 457-487.

8. Djahmi, N.; Dunyach-Rémy, C.; Pantel, A.; Dekhil, M.; Sotto, A.; Lavigne, J.-P. Epidemiology of Carbapenemase-producing Enterobacteriaceae and Acinetobacter baumannii in Mediterranean countries. BioMed Res. Int. 2014, 2014, 1-11. [CrossRef]

9. Anderson, R.E.V.; Boerlin, P. Carbapenemase-producing Enterobacteriaceae in animals and methodologies for their detection. Can. J. Vet. Res. 2020, 84, 3-17.

10. Cheng, Z.; Thomas, P.W.; Ju, L.; Bergstrom, A.; Mason, K.; Clayton, D.; Miller, C.; Bethel, C.R.; Vanpelt, J.; Tierney, D.L.; et al. Evolution of New Delhi metallo- $\beta$-lactamase (NDM) in the clinic: Effects of NDM mutations on stability, zinc affinity, and mono-zinc activity. J. Biol. Chem. 2018, 293, 12606-12618. [CrossRef]

11. Naas, T.; Nordmann, P. Analysis of a Carbapenem-hydrolyzing class A beta-lactamase from Enterobacter cloacae and of its LysR-type regulatory protein. Proc. Natl. Acad. Sci. USA 1994, 91, 7693-7697. [CrossRef]

12. Queenan, A.M.; Bush, K. Carbapenemases: The versatile $\beta$-Lactamases. Clin. Microbiol. Rev. 2007, 20, 440-458. [CrossRef]

13. Bush, K.; Jacoby, G.A. Updated functional classification of $\beta$-Lactamases. Antimicrob. Agents Chemother. 2009, 54, 969-976. [CrossRef] [PubMed]

14. Boyd, S.E.; Livermore, D.M.; Hooper, D.C.; Hope, W.W. Metallo- $\beta$-lactamases: Structure, function, epidemiology, treatment options, and the development pipeline. Antimicrob. Agents Chemother. 2020, 10, e00397-20. [CrossRef] [PubMed] 
15. Mathers, A.J.; Stoesser, N.; Chai, W.; Carroll, J.; Barry, K.; Cherunvanky, A.; Sebra, R.; Kasarskis, A.; Peto, T.E.; Walker, A.S.; et al. Chromosomal integration of the Klebsiella pneumoniae Carbapenemase gene, blaKPC, in Klebsiella species is elusive but not rare. Antimicrob. Agents Chemother. 2016, 61, e01823-16. [CrossRef] [PubMed]

16. Botelho, J.; Roberts, A.P.; León-Sampedro, R.; Grosso, F.; Peixe, L. Carbapenemases on the move: It's good to be on ICEs. Mob. DNA 2018, 9, 37. [CrossRef] [PubMed]

17. Souli, M.; Galani, I.; Giamarellou, H. Emergence of extensively drug-resistant and pandrug-resistant Gram-negative bacilli in Europe. Euro Surveill. Eur. Commun. Dis. Bull. 2008, 13, 19045.

18. Evans, B.A.; Amyes, S. OXA-Lactamases. Clin. Microbiol. Rev. 2014, 27, 241-263. [CrossRef]

19. Codjoe, F.S.; Donkor, E.S. Carbapenem resistance: A review. Med. Sci. 2017, 6, 1. [CrossRef]

20. Moxon, C.A.; Paulus, S. Beta-lactamases in Enterobacteriaceae infections in children. J. Infect. 2016, 72, S41-S49. [CrossRef]

21. Yigit, H.; Queenan, A.M.; Anderson, G.J.; Domenech-Sanchez, A.; Biddle, J.W.; Steward, C.D.; Alberti, S.; Bush, K.; Tenover, F.C. Novel Carbapenem-hydrolyzing $\beta$-Lactamase, KPC-1, from a Carbapenem-resistant strain of Klebsiella pneumoniae. Antimicrob. Agents Chemother. 2001, 45, 1151-1161. [CrossRef]

22. Drew, R.J.; Turton, J.; Hill, R.; Livermore, D.; Woodford, N.; Paulus, S.; Cunliffe, N.A. Emergence of Carbapenem-resistant Enterobacteriaceae in a UK paediatric hospital. J. Hosp. Infect. 2013, 84, 300-304. [CrossRef]

23. Livermore, D.M.; Woodford, N. The $\beta$-lactamase threat in Enterobacteriaceae, Pseudomonas and Acinetobacter. Trends Microbiol. 2006, 14, 413-420. [CrossRef] [PubMed]

24. European Centre for Disease Prevention and Control (ECDC). Risk Assessment on the Spread of Carbapenemase-Producing Enterobacteriaceae (CPE) through Patient Transfer between Healthcare Facilities, with Special Emphasis on Cross-Border Transfer; ECDC Technical Report; ECDC: Stockholm, Sweden, 2011.

25. Azap, O.; Otlu, B.; Yesilkaya, A.; Yakupoğulları, Y. Detection of OXA-48-like Carbapenemase-producing Klebsiella pneumoniae in a tertiary care center in Turkey: Molecular characterization and epidemiology. Balk. Med. J. 2013, 30, 259-260. [CrossRef] [PubMed]

26. Peleg, A.Y.; Hooper, D.C. Hospital-acquired infections due to gram-negative bacteria. N. Engl. J. Med. 2010, 362, 1804-1813. [CrossRef] [PubMed]

27. Choi, S.-H.; Ahn, M.Y.; Chung, J.-W.; Lee, M.-K. In vitro antibacterial activity of Doripenem against gram-negative blood isolates in a Korean tertiary care center. Infect. Chemother. 2015, 47, 175-180. [CrossRef]

28. Aschbacher, R.; Pagani, L.; Doumith, M.; Pike, R.; Woodford, N.; Spoladore, G.; Larcher, C.; Livermore, D.M. Metallo- $\beta$-lactamases among Enterobacteriaceae from routine samples in an Italian tertiary care hospital and long-term care facilities during 2008. Clin. Microbiol. Infect. 2010, 17, 181-189. [CrossRef]

29. Ahn, C.; Syed, A.; Hu, F.; O'Hara, J.A.; Rivera, J.I.; Doi, Y. Microbiological features of KPC-producing Enterobacter isolates identified in a U.S. hospital system. Diagn. Microbiol. Infect. Dis. 2014, 80, 154-158. [CrossRef]

30. Chopra, T.; Rivard, C.; Awali, R.A.; Krishna, A.; Bonomo, R.A.; Perez, F.; Kaye, K.S. Epidemiology of Carbapenem-resistant Enterobacteriaceae at a long-term acute care hospital. Open Forum Infect. Dis. 2018, 5, 224. [CrossRef]

31. Tamma, P.D.; Kazmi, A.; Bergman, Y.; Goodman, K.E.; Ekunseitan, E.; Amoah, J.; Simner, P.J. The likelihood of developing a Carbapenem-resistant infection during the hospital stay. Antimicrob Agents Chemother 2019. [CrossRef]

32. Senchyna, F.; Gaur, R.L.; Sandlund, J.; Truong, C.; Tremintin, G.; Kültz, D.; Gomez, C.A.; Tamburini, F.B.; Andermann, T.M.; Bhatt, A.; et al. Diversity of resistance mechanisms in Carbapenem-resistant Enterobacteriaceae at a health care system in Northern California, from 2013 to 2016. Diagn. Microbiol. Infect. Dis. 2019, 93, 250-257. [CrossRef]

33. Kohler, P.P.; Melano, R.G.; Patel, S.N.; Shafinaz, S.; Faheem, A.; Coleman, B.L.; Green, K.; Armstrong, I.; Almohri, H.; Borgia, S.; et al. Emergence of Carbapenemase-producing Enterobacteriaceae, South-Central Ontario, Canada1. Emerg. Infect. Dis. 2018, 24, 1674-1682. [CrossRef]

34. Souli, M.; Galani, I.; Antoniadou, A.; Papadomichelakis, E.; Poulakou, G.; Panagea, T.; Vourli, S.; Zerva, L.; Armaganidis, A.; Kanellakopoulou, K.; et al. An outbreak of infection due to $\beta$-Lactamase Klebsiella pneumoniae Carbapenemase 2-producing K. pneumoniae in a Greek University Hospital: Molecular characterization, epidemiology, and outcomes. Clin. Infect. Dis. 2010, 50, 364-373. [CrossRef] [PubMed] 
35. Giakkoupi, P.; Papagiannitsis, C.C.; Miriagou, V.; Pappa, O.; Polemis, M.; Tryfinopoulou, K.; Tzouvelekis, L.S.; Vatopoulos, A. An update of the evolving epidemic of blaKPC-2-carrying Klebsiella pneumoniae in Greece (2009-10). J. Antimicrob. Chemother. 2011, 66, 1510-1513. [CrossRef] [PubMed]

36. Grundmann, H.; Livermore, D.M.; Giske, C.G.; Rossolini, G.M.; Campos, J.; Vatopoulos, A.; Gniadkowski, M.; Toth, A.; Pfeifer, Y.; Jarlier, V.; et al. Carbapenem-non-susceptible Enterobacteriaceae in Europe: Conclusions from a meeting of national experts. Eurosurveillance 2010, 15, 15. [CrossRef] [PubMed]

37. Carbonne, A.; Thiolet, J.M.; Fournier, S.; Fortineau, N.; Kassis-Chikhani, N.; Boytchev, I.; Aggoune, M.; Séguier, J.C.; Sénéchal, H.; Tavolacci, M.P.; et al. Control of a multi-hospital outbreak of KPC-producing Klebsiella pneumoniae type 2 in France, September to October 2009. Eurosurveillance 2010, 15, 19734. [CrossRef] [PubMed]

38. Oteo, J.; Saez, D.; Bautista, V.; Fernández-Romero, S.; Hernández-Molina, J.M.; Pérez-Vázquez, M.; Aracil, B.; Campos, J. Carbapenemase-producing Enterobacteriaceae in Spain in 2012. Antimicrob. Agents Chemother. 2013, 57, 6344-6347. [CrossRef] [PubMed]

39. Nordmann, P.; Cuzon, G.; Naas, T. The real threat of Klebsiella pneumoniae Carbapenemase-producing bacteria. Lancet Infect. Dis. 2009, 9, 228-236. [CrossRef]

40. Ducomble, T.; Faucheux, S.; Helbig, U.; Kaisers, U.; Konig, B.; Knaust, A.; Lübbert, C.; Möller, I.; Rodloff, A.; Schweickert, B.; et al. Large hospital outbreak of KPC-2-producing Klebsiella pneumoniae: Investigating mortality and the impact of screening for KPC-2 with polymerase chain reaction. J. Hosp. Infect. 2015, 89, 179-185. [CrossRef]

41. Raro, O.H.F.; Da Silva, R.M.C.; Filho, E.M.R.; Sukiennik, T.C.T.; Stadnik, C.; Dias, C.A.G.; Iglesias, J.O.; Pérez-Vázquez, M. Carbapenemase-producing Klebsiella pneumoniae from transplanted patients in Brazil: Phylogeny, resistome, virulome and mobile genetic elements harboring blaKPC-2 or blaNDM-1. Front. Microbiol. 2020, 11, 1563. [CrossRef]

42. Manenzhe, R.I.; Zar, H.J.; Nicol, M.P.; Kaba, M. The spread of Carbapenemase-producing bacteria in Africa: A systematic review. J. Antimicrob. Chemother. 2014, 70, 23-40. [CrossRef]

43. Singh-Moodley, A.; Perovic, O. Antimicrobial susceptibility testing in predicting the presence of carbapenemase genes in Enterobacteriaceae in South Africa. BMC Infect. Dis. 2016, 16, 536. [CrossRef]

44. Poirel, L.; Pitout, J.D.; Nordmann, P. Carbapenemases: Molecular diversity and clinical consequences. Futur. Microbiol. 2007, 2, 501-512. [CrossRef] [PubMed]

45. Poirel, L.; Bonnin, R.A.; Nordmann, P. Genetic features of the widespread plasmid coding for the Carbapenemase OXA-48. Antimicrob. Agents Chemother. 2011, 56, 559-562. [CrossRef] [PubMed]

46. Lee, C.-R.; Lee, J.H.; Park, K.S.; Kim, Y.B.; Jeong, B.C.; Lee, H.S. Global dissemination of Carbapenemaseproducing Klebsiella pneumoniae: Epidemiology, genetic context, treatment options, and detection methods. Front. Microbiol. 2016, 7, 895. [CrossRef] [PubMed]

47. French, C.; Coope, C.; Conway, L.; Higgins, J.P.; McCulloch, J.; Okoli, G.; Patel, B.; Oliver, I. Control of Carbapenemase-producing Enterobacteriaceae outbreaks in acute settings: An evidence review. J. Hosp. Infect. 2017, 95, 3-45. [CrossRef] [PubMed]

48. Senchyna, F.; Gaur, R.; Sandlund, J.; Truong, C.; Tremintin, G.; Küeltz, D.; Gomez, C.A.; Tamburini, F.B.; Andermann, T.M.; Bhatt, A.S.; et al. Diverse mechanisms of resistance in Carbapenem-resistant Enterobacteriaceae at a health care system in Silicon Valley, California. bioRxiv 2018. [CrossRef]

49. Guo, X.; Rao, Y.; Guo, L.; Xu, H.; Lv, T.; Yu, X.; Chen, Y.; Liu, N.; Han, H.; Zheng, B. Detection and genomic characterization of a Morganella morganii isolate from China that produces NDM-5. Front. Microbiol. 2019, 10, 1156. [CrossRef] [PubMed]

50. Cuzon, G.; Demachy, M.C.; Nordmann, P.; Naas, T. Plasmid-mediated Carbapenem-hydrolyzing $\beta$-Lactamase KPC-2 in Klebsiella pneumoniae isolate from Greece. Antimicrob. Agents Chemother. 2007, 52, 796-797. [CrossRef] [PubMed]

51. Naas, T.; Vedel, G.; Nordmann, P.; Poyart, C. Plasmid-mediated Carbapenem-hydrolyzing $\beta$-Lactamase KPC in a Klebsiella pneumoniae isolate from France. Antimicrob. Agents Chemother. 2005, 49, 4423-4424. [CrossRef]

52. Kumarasamy, K.K.; Toleman, M.A.; Walsh, T.R.; Bagaria, J.; Butt, F.; Balakrishnan, R.; Chaudhary, U.; Doumith, M.; Giske, C.G.; Irfan, S.; et al. Emergence of a new antibiotic resistance mechanism in India, Pakistan, and the UK: A molecular, biological, and epidemiological study. Lancet Infect. Dis. 2010, 10, 597-602. [CrossRef] 
53. Nahid, F.; Khan, A.A.; Rehman, S.; Zahra, R. Prevalence of metallo- $\beta$-lactamase NDM-1-producing multi-drug resistant bacteria at two Pakistani hospitals and implications for public health. J. Infect. Public Heal. 2013, 6, 487-493. [CrossRef]

54. Van Der Bij, A.K.; Pitout, J.D.D. The role of international travel in the worldwide spread of multiresistant Enterobacteriaceae. J. Antimicrob. Chemother. 2012, 67, 2090-2100. [CrossRef] [PubMed]

55. Tijet, N.; Alexander, D.C.; Richardson, D.; Lastovetska, O.; Low, N.E.; Patel, S.N.; Melano, R.G. New Delhi Metallo- $\beta$-Lactamase, Ontario, Canada. Emerg. Infect. Dis. 2011, 17, 306-307. [CrossRef] [PubMed]

56. Bernick, J.; Beliavsky, A.; Bogoch, I.I. Endometritis and bacteremia with a New Delhi Metallo-Beta-Lactamase 1 (NDM-1)-containing organism in a remote traveler. J. Obstet. Gynaecol. Can. 2019, 41, 753-754. [CrossRef] [PubMed]

57. Mataseje, L.F.; Boyd, D.A.; Mulvey, M.R.; Longtin, Y. Report on two hypervirulent Klebsiella pneumoniae producing a blaKPC-2 Carbapenemase from a Canadian patient. Antimicrob Agents Chemother 2019. [CrossRef]

58. Poirel, L.; Vuillemin, X.; Juhas, M.; Masseron, A.; Bechtel-Grosch, U.; Tiziani, S.; Mancini, S.; Nordmann, P. KPC-50 confers resistance to Ceftazidime-Avibactam associated with reduced Carbapenemase activity. Antimicrob. Agents Chemother. 2020, 64, e00321-20. [CrossRef]

59. López, J.; Correa, A.; Navon-Venezia, S.; Torres, J.; Briceno, D.; Montealegre, M.C.; Quinn, J.; Carmeli, Y.; Villegasz, M. Intercontinental spread from Israel to Colombia of a KPC-3-producing klebsiella pneumoniae strain. Clin. Microbiol. Infect. 2011, 17, 52-56. [CrossRef]

60. Adler, A.; Shklyar, M.; Schwaber, M.J.; Navon-Venezia, S.; Dhaher, Y.; Edgar, R.; Solter, E.; Benenson, S.; Masarwa, S.; Carmeli, Y. Introduction of OXA-48-producing Enterobacteriaceae to Israeli hospitals by medical tourism. J. Antimicrob. Chemother. 2011, 66, 2763-2766. [CrossRef]

61. ECDC. European Centre for Disease Prevention and Control. Outbreak of VIM-Producing Carbapenem Resistant Pseudomonas aeruginosa Linked to medical Tourism to Mexico; ECDC: Stockholm, Sweden, 2019.

62. Cheng, V.C.; Wong, S.-C.; Wong, S.C.; Ho, P.-L.; Yuen, K.-Y. Control of Carbapenemase-producing Enterobacteriaceae: Beyond the hospital. EClinicalMedicine 2019, 6, 3-4. [CrossRef]

63. Gentilini, F.; Turba, M.E.; Pasquali, F.; Mion, D.; Romagnoli, N.; Zambon, E.; Terni, D.; Peirano, G.; Pitout, J.D.D.; Parisi, A.; et al. Hospitalized pets as a source of Carbapenem-resistance. Front. Microbiol. 2018, 9, 2872. [CrossRef]

64. Hong, J.S.; Song, W.; Park, H.-M.; Oh, J.-Y.; Chae, J.-C.; Han, J.-I.; Jeong, S.H. First detection of New Delhi Metallo- $\beta$-Lactamase-5-producing Escherichia coli from companion animals in Korea. Microb. Drug Resist. 2019, 25, 344-349. [CrossRef]

65. Adams, R.J.; Kim, S.S.; Mollenkopf, D.F.; Mathys, D.A.; Schuenemann, G.M.; Daniels, J.B.; Wittum, T. Antimicrobial-resistant Enterobacteriaceae recovered from companion animal and livestock environments. Zoonoses Public Health 2018, 65, 519-527. [CrossRef] [PubMed]

66. Stolle, I.; Prenger-Berninghoff, E.; Stamm, I.; Scheufen, S.; Hassdenteufel, E.; Guenther, S.; Bethe, A.; Pfeifer, Y.; Ewers, C. Emergence of OXA-48 Carbapenemase-producing Escherichia coli and Klebsiella pneumoniae in dogs. J. Antimicrob. Chemother. 2013, 68, 2802-2808. [CrossRef] [PubMed]

67. Grönthal, T.; Österblad, M.; Eklund, M.; Jalava, J.; Nykäsenoja, S.; Pekkanen, K.; Rantala, M. Sharing more than friendship-transmission of NDM-5 ST167 and CTX-M-9 ST69 Escherichia coli between dogs and humans in a family, Finland, 2015. Eurosurveillance 2018, 23, 1700497. [CrossRef] [PubMed]

68. Guo, S.; Brouwers, H.J.M.; Cobbold, R.N.; Platell, J.L.; Chapman, T.A.; Barrs, V.R.; Johnson, J.R.; Trott, D.J. Fluoroquinolone-resistant extraintestinal pathogenic Escherichia coli, including O25b-ST131, isolated from faeces of hospitalized dogs in an Australian veterinary referral centre. J. Antimicrob. Chemother. 2013, 68, 1025-1031. [CrossRef]

69. Johnson, J.R.; Clabots, C.; Kuskowski, M.A. Multiple-host sharing, long-term persistence, and virulence of Escherichia coli clones from human and animal household members. J. Clin. Microbiol. 2008, 46, 4078-4082. [CrossRef]

70. Nicolas-Chanoine, M.-H.; Bertrand, X.; Madec, J.-Y. Escherichia coli ST131, an intriguing clonal group. Clin. Microbiol. Rev. 2014, 27, 543-574. [CrossRef]

71. Abraham, S.; O’Dea, M.; Trott, D.J.; Abraham, R.J.; Hughes, D.; Pang, S.; McKew, G.; Cheong, E.Y.L.; Merlino, J.; Saputra, S.; et al. Isolation and plasmid characterization of Carbapenemase (IMP-4) producing Salmonella enterica Typhimurium from cats. Sci. Rep. 2016, 6, 35527. [CrossRef] 
72. Köck, R.; Daniels-Haardt, I.; Becker, K.; Mellmann, A.; Friedrich, A.W.; Mevius, D.; Schwarz, S.; Jurke, A. Carbapenem-resistant Enterobacteriaceae in wildlife, food-producing, and companion animals: A systematic review. Clin. Microbiol. Infect. 2018, 24, 1241-1250. [CrossRef]

73. Wang, Y.; Wang, X.; Schwarz, S.; Zhang, R.; Lei, L.; Liu, X.; Lin, D.; Shen, J. IMP-45-producing multidrug-resistant Pseudomonas aeruginosa of canine origin. J. Antimicrob. Chemother. 2014, 69, 2579-2581. [CrossRef]

74. Rubin, J.; Pitout, J.D. Extended-spectrum $\beta$-lactamase, Carbapenemase and AmpC producing Enterobacteriaceae in companion animals. Veter Microbiol. 2014, 170, 10-18. [CrossRef]

75. Reynolds, M.E.; Phan, H.T.T.; George, S.; Hubbard, A.; Stoesser, N.; Maciuca, E.I.; Crook, D.W.; Timofte, D. Occurrence and characterization of Escherichia coli ST410 co-harbouring blaNDM-5, blaCMY-42 and blaTEM-190 in a dog from the UK. J. Antimicrob. Chemother. 2019, 74, 1207-1211. [CrossRef] [PubMed]

76. Schmidt, J.S.; Kuster, S.P.; Nigg, A.; Dazio, V.; Brilhante, M.; Rohrbach, H.; Bernasconi, O.J.; Büdel, T.; Campos-Madueno, E.I.; Brawand, S.G.; et al. Poor infection prevention and control standards are associated with environmental contamination with Carbapenemase-producing Enterobacterales and other multidrug-resistant bacteria in Swiss companion animal clinics. Antimicrob. Resist. Infect. Control. 2020, 9 , 1-13. [CrossRef] [PubMed]

77. Gibson, J.; Morton, J.; Cobbold, R.; Sidjabat, H.; Filippich, L.; Trott, D. Multidrug-resistant E. coli and Enterobacter extraintestinal infection in 37 dogs. J. Veter. Intern. Med. 2008, 22, 844-850. [CrossRef] [PubMed]

78. Fischer, J.; Rodríguez, I.; Schmoger, S.; Friese, A.; Roesler, U.; Helmuth, R.; Guerra, B. Escherichia coli producing VIM-1 Carbapenemase isolated on a pig farm. J. Antimicrob. Chemother. 2012, 67, 1793-1795. [CrossRef]

79. Poirel, L.; Berçot, B.; Millemann, Y.; Bonnin, R.A.; Pannaux, G.; Nordmann, P. Carbapenemase-producing Acinetobacter spp. in Cattle, France. Emerg. Infect. Dis. 2012, 18, 523-525. [CrossRef]

80. Fischer, J.; Rodríguez, I.; Schmoger, S.; Friese, A.; Roesler, U.; Helmuth, R.; Guerra, B. Salmonella enterica subsp. enterica producing VIM-1 Carbapenemase isolated from livestock farms. J. Antimicrob. Chemother. 2012, 68, 478-480. [CrossRef]

81. Fischer, J.; José, M.S.; Roschanski, N.; Schmoger, S.; Baumann, B.; Irrgang, A.; Friese, A.; Roesler, U.; Helmuth, R.; Guerra, B. Spread and persistence of VIM-1 Carbapenemase-producing Enterobacteriaceae in three German swine farms in 2011 and 2012. Veter. Microbiol. 2017, 200, 118-123. [CrossRef]

82. Wang, Y.; Wu, C.; Zhang, Q.; Qi, J.; Liu, H.; Wang, Y.; He, T.; Ma, L.; Lai, J.; Shen, Z.; et al. Identification of New Delhi Metallo- $\beta$-lactamase 1 in Acinetobacter lwoffii of food animal origin. PLoS ONE 2012, 7, e37152. [CrossRef]

83. He, T.; Wei, R.; Zhang, L.; Sun, L.; Pang, M.; Wang, R.; Wang, Y. Characterization of NDM-5-positive extensively resistant Escherichia coli isolates from dairy cows. Veter. Microbiol. 2017, 207, 153-158. [CrossRef]

84. Liu, Z.; Li, J.; Wang, X.; Liu, D.; Ke, Y.; Wang, Y.; Shen, J. Novel variant of New Delhi Metallo- $\beta$-lactamase, NDM-20, in Escherichia coli. Front. Microbiol. 2018, 9, 248. [CrossRef]

85. Morrison, B.J.; Rubin, J. Carbapenemase producing bacteria in the food supply escaping detection. PLoS ONE 2015, 10, e0126717. [CrossRef]

86. Abdallah, H.; Reuland, E.A.; Wintermans, B.B.; Al Naiemi, N.; Koek, A.; Abdelwahab, A.M.; Ammar, A.M.; Mohamed, A.A.; Vandenbroucke-Grauls, C.M.J.E. Extended-spectrum $\beta$-Lactamases and/or Carbapenemases-producing Enterobacteriaceae isolated from retail chicken meat in Zagazig, Egypt. PLoS ONE 2015, 10, e0136052. [CrossRef] [PubMed]

87. Ahmad, K.; Khattak, F.; Ali, A.; Rahat, S.; Noor, S.; Mahsood, N.; Somayya, R. Carbapenemases and extended-spectrum $\beta$-Lactamase-producing multidrug-resistant Escherichia coli isolated from retail chicken in Peshawar: First report from Pakistan. J. Food Prot. 2018, 81, 1339-1345. [CrossRef] [PubMed]

88. Yao, X.; Doi, Y.; Zeng, L.; Lv, L.; Liu, J.-H. Carbapenem-resistant and colistin-resistant Escherichia coli co-producing NDM-9 and MCR-1. Lancet Infect. Dis. 2016, 16, 288-289. [CrossRef]

89. VIM-1-producing Salmonella infantis isolated from swine and minced pork meat in Germany. J. Antimicrob. Chemother. 2017, 72, 2131-2133. [CrossRef]

90. Wang, W.; Baloch, Z.; Peng, Z.; Hu, Y.; Xu, J.; Fanning, S.; Li, F. Genomic characterization of a large plasmid containing a bla NDM-1 gene carried on Salmonella enterica serovar Indiana C629 isolate from China. BMC Infect. Dis. 2017, 17, 479. [CrossRef] 
91. Zhang, Q.; Lv, L.; Huang, X.; Huang, Y.; Zhuang, Z.; Lu, J.; Liu, E.; Wan, M.; Xun, H.; Zhang, Z.; et al. Rapid increase in Carbapenemase-producing Enterobacteriaceae in retail meat driven by the spread of the blaNDM-5-carrying IncX3 plasmid in China from 2016 to 2018. Antimicrob. Agents Chemother. 2019, 63, e00573-19. [CrossRef]

92. Roschanski, N.; Guenther, S.; Vu, T.T.T.; Fischer, J.; Semmler, T.; Huehn, S.; Alter, T.; Roesler, U. VIM-1 Carbapenemase-producing Escherichia coli isolated from retail seafood, Germany 2016. Eurosurveillance 2017, 22, 17-32. [CrossRef]

93. Janecko, N.; Martz, S.-L.; Avery, B.P.; Daignault, D.; Desruisseau, A.; Boyd, D.; Irwin, R.J.; Mulvey, M.R.; Reid-Smith, R.J. Carbapenem-resistant Enterobacter spp. in retail seafood imported from Southeast Asia to Canada. Emerg. Infect. Dis. 2016, 22, 1675-1677. [CrossRef]

94. Brouwer, M.S.; Tehrani, K.H.M.E.; Rapallini, M.; Geurts, Y.; Kant, A.; Harders, F.; Mashayekhi, V.; Martin, N.I.; Bossers, A.; Mevius, D.J.; et al. Novel Carbapenemases FLC-1 and IMI-2 encoded by an Enterobacter cloacae complex isolated from food products. Antimicrob. Agents Chemother. 2019, 63, e02338-18. [CrossRef]

95. Diab, M.; Hamze, M.; Bonnet, R.; Saras, E.; Madec, J.-Y.; Haenni, M. OXA-48 and CTX-M-15 extended-spectrum beta-lactamases in raw milk in Lebanon: Epidemic spread of dominant Klebsiella pneumoniae clones. J. Med. Microbiol. 2017, 66, 1688-1691. [CrossRef] [PubMed]

96. Wang, J.; Yao, X.; Luo, J.; Lv, L.; Zeng, Z.; Liu, J.-H. Emergence of Escherichia coli co-producing NDM-1 and KPC-2 Carbapenemases from a retail vegetable, China. J. Antimicrob. Chemother. 2017, 73, 252-254. [CrossRef]

97. Touati, A.; Mairi, A.; Baloul, Y.; Lalaoui, R.; Bakour, S.; Thighilt, L.; Gharout, A.; Rolain, J.-M. First detection of Klebsiella pneumoniae producing OXA-48 in fresh vegetables from Béjaïa city, Algeria. J. Glob. Antimicrob. Resist. 2017, 9, 17-18. [CrossRef] [PubMed]

98. Zurfluh, K.; Poirel, L.; Nordmann, P.; Klumpp, J.; Stephan, R. First detection of Klebsiella variicola producing OXA-181 Carbapenemase in fresh vegetable imported from Asia to Switzerland. Antimicrob. Resist. Infect. Control. 2015, 4, 1-3. [CrossRef] [PubMed]

99. Hsu, L.Y.; Apisarnthanarak, A.; Khan, E.; Suwantarat, N.; Ghafur, A.; Tambyah, P.A. Carbapenem-resistant Acinetobacter baumannii and Enterobacteriaceae in South and Southeast Asia. Clin. Microbiol. Rev. 2016, 30, 1-22. [CrossRef]

100. Walsh, T.R.; Weeks, J.; Livermore, D.M.; Toleman, M.A. Dissemination of NDM-1 positive bacteria in the New Delhi environment and its implications for human health: An environmental point prevalence study. Lancet Infect. Dis. 2011, 11, 355-362. [CrossRef]

101. Lerner, A.; Adler, A.; Abu-Hanna, J.; Meitus, I.; Navon-Venezia, S.; Carmeli, Y. Environmental contamination by Carbapenem-resistant Enterobacteriaceae. J. Clin. Microbiol. 2012, 51, 177-181. [CrossRef]

102. Chen, W.K.; Yang, Y.; Tan, B.H. Increased mortality among Carbapenemase-producing Carbapenem-resistant Enterobacteriaceae carriers who developed clinical isolates of another genotype. Open Forum Infect. Dis. 2019, 6, 6. [CrossRef]

103. Weingarten, R.A.; Johnson, R.C.; Conlan, S.; Ramsburg, A.M.; Dekker, J.P.; Lau, A.F.; Khil, P.; Odom, R.T.; Deming, C.; Park, M.; et al. Genomic analysis of hospital plumbing reveals diverse reservoir of bacterial plasmids conferring Carbapenem resistance. mBio 2018, 9, 02011-02017. [CrossRef]

104. Khan, A.U.; Parvez, S. Detection of bla NDM-4 in Escherichia coli from hospital sewage. J. Med. Microbiol. 2014, 63, 1404-1406. [CrossRef]

105. Zurfluh, K.; Hächler, H.; Nüesch-Inderbinen, M.; Stephan, R. Characteristics of extended-spectrum $\beta$-Lactamase-and Carbapenemase-producing Enterobacteriaceae isolates from rivers and lakes in Switzerland. Appl. Environ. Microbiol. 2013, 79, 3021-3026. [CrossRef] [PubMed]

106. Khan, F.A.; Hellmark, B.; Ehricht, R.; Söderquist, B.; Jass, J. Related Carbapenemase-producing Klebsiella isolates detected in both a hospital and associated aquatic environment in Sweden. Eur. J. Clin. Microbiol. Infect. Dis. 2018, 37, 2241-2251. [CrossRef] [PubMed]

107. Piedra-Carrasco, N.; Fàbrega, A.; Calero-Cáceres, W.; Cornejo-Sánchez, T.; Brown-Jaque, M.; Mir-Cros, A.; Muniesa, M.; González-López, J.J. Carbapenemase-producing Enterobacteriaceae recovered from a Spanish river ecosystem. PLoS ONE 2017, 12, e0175246. [CrossRef] [PubMed]

108. Hoelle, J.; Johnson, J.R.; Johnston, B.D.; Kinkle, B.; Boczek, L.; Ryu, H.; Hayes, S. Survey of US wastewater for Carbapenem-resistant Enterobacteriaceae. J. Water Health 2019, 17, 219-226. [CrossRef] [PubMed] 
109. Mollenkopf, D.F.; Stull, J.W.; Mathys, D.A.; Bowman, A.S.; Feicht, S.M.; Grooters, S.V.; Daniels, J.B.; Wittum, T. Carbapenemase-Producing Enterobacteriaceae Recovered from the Environment of a Swine Farrow-to-finish operation in the United States. Antimicrob. Agents Chemother. 2016, 61, 61. [CrossRef] [PubMed]

110. Vikram, A.; Schmidt, J.W. Functional blaKPC-2 sequences are present in U.S. beef cattle feces regardless of antibiotic use. Foodborne Pathog. Dis. 2018, 15, 444-448. [CrossRef] [PubMed]

111. Hrenovic, J.; Music, M.S.; Durn, G.; Dekic, S.; Hunjak, B.; Kisic, I. Carbapenem-resistant Acinetobacter baumannii recovered from swine manure. Microb. Drug Resist. 2019, 25, 725-730. [CrossRef] [PubMed]

112. Tang, B.; Chang, J.; Cao, L.; Luo, Q.-X.; Xu, H.; Lyu, W.; Qian, M.; Ji, X.; Zhang, Q.; Xia, X.; et al. Characterization of an NDM-5 Carbapenemase-producing Escherichia coli ST156 isolate from a poultry farm in Zhejiang, China. BMC Microbiol. 2019, 19, 82. [CrossRef] [PubMed]

113. Adegoke, A.A.; Fatunla, O.K.; Okoh, A.I. Critical threat associated with carbapenem-resistant gram-negative bacteria: Prioritizing water matrices in addressing total antibiotic resistance. Ann. Microbiol. 2020, 70, 1-13. [CrossRef]

114. Lepuschitz, S.; Schill, S.; Stoeger, A.; Pekard-Amenitsch, S.; Huhulescu, S.; Inreiter, N.; Hartl, R.; Kerschner, H.; Sorschag, S.; Springer, B.; et al. Whole genome sequencing reveals resemblance between ESBL-producing and carbapenem resistant Klebsiella pneumoniae isolates from Austrian rivers and clinical isolates from hospitals. Sci. Total. Environ. 2019, 662, 227-235. [CrossRef]

115. Tanner, W.D.; Vanderslice, J.A.; Goel, R.K.; Leecaster, M.K.; Fisher, M.A.; Olstadt, J.; Gurley, C.M.; Morris, A.G.; Seely, K.A.; Chapman, L.; et al. Multi-state study of Enterobacteriaceae harboring extended-spectrum beta-lactamase and Carbapenemase genes in U.S. drinking water. Sci. Rep. 2019, 9, 3938. [CrossRef]

116. Hamza, D.; Dorgham, S.; Ismael, E.; El-Moez, S.I.A.; ElHariri, M.; Elhelw, R.; Hamza, E. Emergence of $\beta$-lactamase-and Carbapenemase-producing Enterobacteriaceae at integrated fish farms. Antimicrob. Resist. Infect. Control. 2020, 9, 1-12. [CrossRef]

117. Bonomo, R.A.; Burd, E.M.; Conly, J.; Limbago, B.M.; Poirel, L.; Segre, J.A.; Westblade, L.F. Carbapenemase-producing organisms: A global scourge. Clin. Infect. Dis. 2017, 66, 1290-1297. [CrossRef]

118. Nordmann, P.; Dortet, L.; Poirel, L. Carbapenem resistance in Enterobacteriaceae: Here is the storm! Trends Mol. Med. 2012, 18, 263-272. [CrossRef] [PubMed]

119. Yong, D.; Toleman, M.A.; Giske, C.G.; Cho, H.S.; Sundman, K.; Lee, K.; Walsh, T.R. Characterization of a new Metallo- $\beta$-Lactamase gene, blaNDM-1, and a novel erythromycin esterase gene carried on a unique genetic structure in Klebsiella pneumoniae sequence type 14 from India. Antimicrob. Agents Chemother. 2009, 53, 5046-5054. [CrossRef] [PubMed]

120. Bush, K.; Bradford, P.A. Epidemiology of $\beta$-Lactamase-producing pathogens. Clin. Microbiol. Rev. 2020, 33, 33. [CrossRef] [PubMed]

121. Pournaras, S.; Tsakris, A.; Maniati, M.; Tzouvelekis, L.S.; Maniatis, A.N. Novel variant (blaVIM-4) of the Metallo- $\beta$-Lactamase gene blaVIM-1 in a clinical strain of Pseudomonas aeruginosa. Antimicrob. Agents Chemother. 2002, 46, 4026-4028. [CrossRef] [PubMed]

122. Matsumura, Y.; Peirano, G.; Motyl, M.R.; Adams, M.D.; Chen, L.; Kreiswirth, B.; DeVinney, R.; Pitout, J.D.D. Global molecular epidemiology of IMP-producing Enterobacteriaceae. Antimicrob. Agents Chemother. 2017, 61, e02729-16. [CrossRef] [PubMed]

123. Shen, Z.; Hu, Y.; Sun, Q.; Hu, F.; Zhou, H.; Shu, L.; Ma, T.; Shen, Y.; Wang, Y.; Li, J.; et al. Emerging carriage of NDM-5 and MCR-1 in Escherichia coli from healthy people in multiple regions in China: A cross sectional observational study. EClinicalMedicine 2018, 6, 11-20. [CrossRef]

124. Li, J.; Bi, Z.; Ma, S.; Chen, B.; Cai, C.; He, J.; Schwarz, S.; Sun, C.; Zhou, Y.; Yin, J.; et al. Inter-host transmission of Carbapenemase-producing Escherichia coli among humans and backyard animals. Environ. Health Perspect. 2019, 127, 107009. [CrossRef]

125. Zhai, R.; Fu, B.; Shi, X.; Sun, C.; Liu, Z.; Wang, S.; Shen, Z.; Walsh, T.R.; Cai, C.; Wang, Y.; et al. Contaminated in-house environment contributes to the persistence and transmission of NDM-producing bacteria in a Chinese poultry farm. Environ. Int. 2020, 139, 105715. [CrossRef] [PubMed]

126. ECDC. European Centre for Disease Prevention and Control. Carbapenem-Resistant Enterobacteriaceae, second Update; ECDC: Stockholm, Sweden, 2019.

127. Schrijver, R.; Stijntjes, M.; Rodríguez-Baño, J.; Tacconelli, E.; Rajendran, N.B.; Voss, A. Review of antimicrobial resistance surveillance programmes in livestock and meat in EU with focus on humans. Clin. Microbiol. Infect. 2018, 24, 577-590. [CrossRef] [PubMed] 
128. Bonardi, S.; Pitino, R. Carbapenemase-producing bacteria in food-producing animals, wildlife and environment: A challenge for human health. Ital. J. Food Saf. 2019, 8, 7956. [CrossRef] [PubMed]

129. Wang, Y.; Zhang, R.; Li, J.; Wu, Z.; Yin, W.; Schwarz, S.; Tyrrell, J.M.; Zheng, Y.; Wang, S.; Shen, Z.; et al. Comprehensive resistome analysis reveals the prevalence of NDM and MCR-1 in Chinese poultry production. Nat. Microbiol. 2017, 2, 16260. [CrossRef]

130. Elshafiee, E.A.; Nader, S.M.; Dorgham, S.M.; Hamza, D. Carbapenem-resistant Pseudomonas aeruginosa originating from farm animals and people in Egypt. J. Veter.-Res. 2019, 63, 333-337. [CrossRef]

131. Cui, X.; Zhang, H.; Du, H. Carbapenemases in Enterobacteriaceae: Detection and antimicrobial therapy. Front. Microbiol. 2019, 10, 1823. [CrossRef]

132. Balloux, F.; Brynildsrud, O.B.; Van Dorp, L.; Shaw, L.P.; Chen, H.; Harris, K.A.; Wang, H.; Eldholm, V. From theory to practice: Translating whole-genome sequencing (WGS) into the clinic. Trends Microbiol. 2018, 26, 1035-1048. [CrossRef]

133. Lynch, T.; Petkau, A.; Knox, N.; Graham, M.; Van Domselaar, G. A Primer on infectious disease bacterial genomics. Clin. Microbiol. Rev. 2016, 29, 881-913. [CrossRef]

134. Partridge, S.R. Analysis of antibiotic resistance regions in Gram-negative bacteria. FEMS Microbiol. Rev. 2011, 35, 820-855. [CrossRef]

135. Stokes, H.W.; Gillings, M.R. Gene flow, mobile genetic elements and the recruitment of antibiotic resistance genes into Gram-negative pathogens. FEMS Microbiol. Rev. 2011, 35, 790-819. [CrossRef]

136. Toleman, M.A.; Walsh, T.R. Combinatorial events of insertion sequences and ICE in Gram-negative bacteria. FEMS Microbiol. Rev. 2011, 35, 912-935. [CrossRef] [PubMed]

137. Hardiman, C.A.; Weingarten, R.A.; Conlan, S.; Khil, P.; Dekker, J.P.; Mathers, A.J.; Sheppard, A.E.; Segre, J.A.; Frank, K.M. Horizontal transfer of Carbapenemase-encoding plasmids and comparison with hospital epidemiology data. Antimicrob. Agents Chemother. 2016, 60, 4910-4919. [CrossRef]

138. Liapis, E.; Bour, M.; Triponney, P.; Jové, T.; Zahar, J.-R.; Valot, B.; Jeannot, K.; Plésiat, P. Identification of diverse integron and plasmid structures carrying a novel Carbapenemase among Pseudomonas species. Front. Microbiol. 2019, 10, 404. [CrossRef] [PubMed]

139. Sugawara, Y.; Akeda, Y.; Sakamoto, N.; Takeuchi, D.; Motooka, D.; Nakamura, S.; Hagiya, H.; Yamamoto, N.; Nishi, I.; Yoshida, H.; et al. Genetic characterization of blaNDM-harboring plasmids in carbapenem-resistant Escherichia coli from Myanmar. PLoS ONE 2017, 12, e0184720. [CrossRef]

140. Carattoli, A.; Miriagou, V.; Bertini, A.; Loli, A.; Colinon, C.; Villa, L.; Whichard, J.M.; Rossolini, G.M. Replicon typing of plasmids encoding resistance to newer $\beta$-Lactams. Emerg. Infect. Dis. 2006, 12, 1145-1148. [CrossRef] [PubMed]

141. Carattoli, A. Resistance plasmid families in Enterobacteriaceae. Antimicrob. Agents Chemother. 2009, 53, 2227-2238. [CrossRef]

142. Cuzon, G.; Naas, T.; Truong, H.; Villegas, M.-V.; Wisell, K.T.; Carmeli, Y.; Gales, A.C.; Navon-Venezia, S.; Quinn, J.P.; Nordmann, P. Worldwide diversity of Klebsiella pneumoniae that produce $\beta$-Lactamase blaKPC-2gene1. Emerg. Infect. Dis. 2010, 16, 1349-1356. [CrossRef]

143. Zhang, X.; Wang, W.; Yu, H.; Wang, M.; Zhang, H.; Lv, J.; Tang, Y.-W.; Kreiswirth, B.N.; Du, H.; Chen, L.; et al. New Delhi Metallo- $\beta$-Lactamase 5-producing Klebsiella pneumoniae sequence type 258, Southwest China, 2017. Emerg. Infect. Dis. 2019, 25, 1209-1213. [CrossRef]

144. Lopes, B.S.; Amyes, S.G.B. Role of ISAba1 and ISAba125 in governing the expression of bla ADC in clinically relevant Acinetobacter baumannii strains resistant to cephalosporins. J. Med. Microbiol. 2012, 61, 1103-1108. [CrossRef]

145. Figueiredo, S.; Poirel, L.; Croize, J.; Recule, C.; Nordmann, P. In vivo selection of reduced susceptibility to Carbapenems in Acinetobacter baumannii related to ISAba1-mediated overexpression of the natural blaOXA-66 Oxacillinase gene. Antimicrob. Agents Chemother. 2009, 53, 2657-2659. [CrossRef]

146. Bontron, S.; Nordmann, P.; Poirel, L. Transposition of Tn125encoding the NDM-1 Carbapenemase in Acinetobacter baumannii. Antimicrob. Agents Chemother. 2016, 60, AAC.01755-16. [CrossRef]

147. Mukherjee, S.; Bhattacharjee, A.; Naha, S.; Majumdar, T.; Debbarma, S.K.; Kaur, H.; Dutta, S.; Basu, S. Molecular characterization of NDM-1-producing Klebsiella pneumoniae ST29, ST347, ST1224, and ST2558 causing sepsis in neonates in a tertiary care hospital of North-East India. Infect. Genet. Evol. 2019, 69, 166-175. [CrossRef] [PubMed] 
148. Antunes, N.T.; Lamoureaux, T.L.; Toth, M.; Stewart, N.K.; Frase, H.; Vakulenko, S.B. Class D $\beta$-Lactamases: Are they all Carbapenemases? Antimicrob. Agents Chemother. 2014, 58, 2119-2125. [CrossRef] [PubMed]

149. Cheruvanky, A.; Stoesser, N.; Sheppard, A.E.; Crook, D.W.; Hoffman, P.S.; Weddle, E.; Carroll, J.; Sifri, C.D.; Chai, W.; Barry, K.; et al. Enhanced Klebsiella pneumoniae Carbapenemase expression from a novel Tn4401 deletion. Antimicrob. Agents Chemother. 2017, 61, e00025-17. [CrossRef]

150. Moellering, R.C. NDM-1-A cause for worldwide concern. New Engl. J. Med. 2010, 363, 2377-2379. [CrossRef]

151. Nordmann, P.; Poirel, L.; Toleman, M.A.; Walsh, T.R. Does broad-spectrum beta-lactam resistance due to NDM-1 herald the end of the antibiotic era for treatment of infections caused by Gram-negative bacteria? J. Antimicrob. Chemother. 2011, 66, 689-692. [CrossRef]

152. Li, X.; Mu, X.; Zhang, P.; Zhao, D.-D.; Ji, J.; Quan, J.; Zhu, Y.; Yu, Y. Detection and characterization of a clinical Escherichia coli ST3204 strain coproducing NDM-16 and MCR-1. Infect. Drug Resist. 2018, 11, 1189-1195. [CrossRef]

153. Yang, Q.E.; Agouri, S.R.; Tyrrell, J.M.; Walsh, T.R. Heavy metal resistance genes are associated with blaNDM-1and blaCTX-M-15-carrying Enterobacteriaceae. Antimicrob. Agents Chemother. 2018, 62, e02642-17. [CrossRef]

154. Liu, C.M.; Stegger, M.; Aziz, M.; Johnson, T.J.; Waits, K.; Nordstrom, L.; Gauld, L.; Weaver, B.; Rolland, D.; Statham, S.; et al. Escherichia coli ST131-H22 as a foodborne uropathogen. mBio 2018, 9, e00470-18. [CrossRef]

155. Pecora, N.D.; Zhao, X.; Nudel, K.; Hoffmann, M.; Li, N.; Onderdonk, A.B.; Yokoe, D.; Brown, E.; Allard, M.; Bry, L. Diverse vectors and mechanisms spread New Delhi Metallo- $\beta$-Lactamases among Carbapenem-resistant Enterobacteriaceae in the Greater Boston area. Antimicrob. Agents Chemother. 2018, 63, e02040-18. [CrossRef]

156. Muir, A.; Weinbren, M. New Delhi metallo- $\beta$-lactamase: A cautionary tale. J. Hosp. Infect. 2010, 75, $239-240$. [CrossRef] [PubMed]

157. Wu, W.; Feng, Y.; Tang, G.; Qiao, F.; McNally, A.; Zong, Z. NDM Metallo- $\beta$-Lactamases and their bacterial producers in health care settings. Clin. Microbiol. Rev. 2019, 32, e00115-18. [CrossRef] [PubMed]

158. Carrër, A.; Poirel, L.; Yilmaz, M.; Akan, O.A.; Feriha, C.; Cuzon, G.; Matar, G.; Honderlick, P.; Nordmann, P. Spread of OXA-48-encoding plasmid in Turkey and beyond. Antimicrob. Agents Chemother. 2010, 54, 1369-1373. [CrossRef]

159. Xie, L.; Dou, Y.; Zhou, K.; Chen, Y.; Han, L.; Guo, X.; Sun, J. Coexistence of blaOXA-48 and truncated blaNDM-1 on different plasmids in a Klebsiella pneumoniae isolate in China. Front. Microbiol. 2017, 8, 133. [CrossRef] [PubMed]

160. Naas, T.; Cuzon, G.; Villegas, M.-V.; Lartigue, M.-F.; Quinn, J.P.; Nordmann, P. Genetic structures at the origin of acquisition of the $\beta$-Lactamase blaKPC gene. Antimicrob. Agents Chemother. 2008, 52, 1257-1263. [CrossRef] [PubMed]

161. Galetti, R.; Andrade, L.N.; Varani, A.M.; Darini, A.L.C. A phage-like plasmid carrying blaKPC-2 gene in Carbapenem-resistant Pseudomonas aeruginosa. Front. Microbiol. 2019, 10, 572. [CrossRef]

162. Rasheed, J.K.; Biddle, J.W.; Anderson, K.F.; Washer, L.; Chenoweth, C.; Perrin, J.; Newton, D.W.; Patel, J.B. Detection of the Klebsiella pneumoniae Carbapenemase type 2 Carbapenem-hydrolyzing enzyme in clinical isolates of Citrobacter freundii and K. oxytoca carrying a common plasmid. J. Clin. Microbiol. 2008, 46, 2066-2069. [CrossRef]

163. Schweizer, C.; Bischoff, P.; Bender, J.; Kola, A.; Gastmeier, P.; Hummel, M.; Klefisch, F.-R.; Schoenrath, F.; Frühauf, A.; Pfeifer, Y. Plasmid-mediated transmission of KPC-2 Carbapenemase in Enterobacteriaceae in critically ill patients. Front. Microbiol. 2019, 10, 276. [CrossRef]

164. Cai, J.C.; Zhou, H.W.; Zhang, R.; Chen, G.-X. Emergence of Serratia marcescens, Klebsiella pneumoniae, and Escherichia coli isolates possessing the plasmid-mediated Carbapenem-hydrolyzing $\beta$-Lactamase KPC-2 in intensive care units of a Chinese hospital. Antimicrob. Agents Chemother. 2008, 52, 2014-2018. [CrossRef]

(C) 2020 by the authors. Licensee MDPI, Basel, Switzerland. This article is an open access article distributed under the terms and conditions of the Creative Commons Attribution (CC BY) license (http://creativecommons.org/licenses/by/4.0/). 